University of Nebraska - Lincoln

DigitalCommons@University of Nebraska - Lincoln

Finance Department Faculty Publications

Finance Department

Spring 2012

\title{
Shareholder Returns from Supplying Trade Credit
}

Matthew D. Hill

University of Mississippi, mhill@bus.olemiss.edu

G. Wayne Kelly

University of Southern Mississippi, gary.kelly@usm.edu

G. Brandon Lockhart

University of Nebraska-Lincoln, lockhart@unl.edu

Follow this and additional works at: https://digitalcommons.unl.edu/financefacpub

Part of the Finance and Financial Management Commons

Hill, Matthew D.; Kelly, G. Wayne; and Lockhart, G. Brandon, "Shareholder Returns from Supplying Trade Credit" (2012). Finance Department Faculty Publications. 27.

https://digitalcommons.unl.edu/financefacpub/27

This Article is brought to you for free and open access by the Finance Department at DigitalCommons@University of Nebraska - Lincoln. It has been accepted for inclusion in Finance Department Faculty Publications by an authorized administrator of DigitalCommons@University of Nebraska - Lincoln. 


\title{
Shareholder Returns from Supplying Trade Credit
}

\author{
Matthew D. Hill, G. Wayne Kelly, and G. Brandon Lockhart
}

\begin{abstract}
We examine shareholder wealth implications of supplying financing to customers. Robust results suggest that excess returns and changes in trade receivables are directly and significantly related. Further evidence indicates the value of receivables is higher for suppliers with stronger motives relating to operating and contracting costs. The results also suggest a discounted value of receivables for financially unconstrained firms. Overall, we conclude that investors recognize trade credit as an effective instrument in mitigating frictions hindering sales growth. Thus, certain suppliers are positioned to derive increased strategic benefits from credit policy.
\end{abstract}

Providing trade credit is important to many suppliers whose future sales and nonsalvageable relationship-specific investments depend on customers' financing ability (Smith, 1987). Nadiri (1969) emphasizes the role of supplier financing by comparing trade credit to a capital investment that yields returns over time through gains in market share. Although Kim and Atkins (1978) and Sartoris and Hill $(1981,1983)$ demonstrate theoretically the impact of trade credit policies on suppliers' firm value, the literature lacks an empirical examination of this impact. This study seeks to fill this void by estimating the shareholder wealth effects of providing financing to customers.

The volume of accounts receivable held by publicly traded firms warrants a better understanding of its influence on equity values. For our sample, the average firm's investment in receivables is roughly $\$ 360$ million and the mean receivables-to-assets ratio is $18 \%$. These statistics echo findings in previous studies (Mian and Smith, 1992; Molina and Preve, 2009) and reiterate the important role of trade credit in the US economy.

Our results indicate a direct and economically significant relation between shareholder wealth and trade receivables. This is consistent with investors recognizing the future revenue growth associated with lending to customers and the liquidity reserve provided by receivables (Emery, 1984). Estimates for the market value of an additional dollar in receivables is significantly less than for a marginal dollar in cash, as theory predicts given the additional costs in carrying and/or liquidating receivables. Quantitative and qualitative inferences are robust to firm-specific heterogeneity and after redefining the receivables measure.

Matthew D. Hill is an Assistant Professor and the J. Ed Turner Chair of Real Estate in the Department of Finance at the University of Mississippi, University, Mississippi.

G. Wayne Kelly is an Associate Professor in the Department of Finance, Real Estate, and Business Law at the University of Southern Mississippi, Hattiesburg, Mississippi.

G. Brandon Lockhart is an Assistant Professor in the Department of Finance at the University of Nebraska-Lincoln, Lincoln, Nebraska.

We thank two anonymous referees for Financial Management, and Janet Kiholm Smith, Lorenzo Preve (Discussant), Bill Christie (Editor), and conference seminar participants at the 2010 FMA Annual Meeting (New York) for helpful comments and suggestions. 
Additional results show that certain product market characteristics govern the market value of trade receivables. Specifically, the value of supplier financing increases with sales volatility, supporting Emery's (1987) view that sales queues reduce the costs of storing inventory and altering plant capacity. Further evidence suggests the equity market perceives the product quality motive of trade credit. The value of receivables significantly decreases (increases) with reputational capital (research and development [R\&D] expenditures). Results also support differences in the value of supplier financing across industries. We do not find that the length of the production cycle influences the relationship between excess returns and changes in receivables.

We also examine the influence of financial constraint on the value of receivables. Results indicate investors discount the receivables of unconstrained firms, despite the likelihood that these firms have cost advantages in extending trade credit. This finding is consistent with the equity market viewing receivables as a substitute for cash, at least within the financial constraint paradigm. In addition, we find that the value of receivables is unrelated to prior period cash holdings, but decreases significantly with leverage levels.

This research extends the trade credit literature by linking firms' motives in extending trade credit to the equity market's assessment of these motives. Several studies examine the determinants of supplier financing, focusing on the preferences, and expectations of both buyers and suppliers. ${ }^{1}$ Our approach connects excess stock returns to changes in receivables, providing evidence that trade credit policy is valued by shareholders. Further, our value approach provides a novel examination of the motives underlying trade credit extension, which is important as firms may use capital market proceeds to finance receivables. Overall, variation in the market value of receivables across product market characteristics and financial constraint is consistent with the existing research suggesting the various strategic dimensions of trade credit in enhancing firm value (Petersen and Rajan, 1997).

A related study by Molina and Preve (2009) examines reductions in trade credit as an additional cost of financial distress and finds that performance is negatively related to the interaction between financial distress and extreme reductions in trade credit supplied. Our results and contributions are unique in that we examine the link between shareholder wealth and typical trade credit behavior. We do not limit our focus to extreme reductions in trade credit as a consequence of distress. Further differentiating this study, we find that the degree to which suppliers can use trade credit to increase shareholder wealth varies with product market dynamics and financial constraints. Thus, firms and financial analysts alike should consider these characteristics when assessing the efficiency of trade credit policies and behavior.

We also extend the working capital management literature. Shin and Soenen (1998) and Deloof (2003) examine the relation between operating performance and the length of time funds are invested in the operating cycle, leaving the isolated value implications of receivables unexamined. Although the value of cash holdings is the focus of many studies in the cash management literature, the market value of trade credit is absent, despite the margin by which investments in receivables exceed cash holdings for our mean sample firm. ${ }^{2,3}$

1. Research empirically examining the determinants of trade credit extension include Nadiri (1969), Deloof and Jegers (1996), Petersen and Rajan (1997), Love, Preve, and Sarria-Allende (2007), Giannetti, Burkart, and Ellingsen (2008), Bougheas, Mateut, and Mizen (2009), Molina and Preve (2009), and Garcia-Teruel and Martinez-Solano (2010).

2. Existing research examines various issues associated with the market value of cash. Faulkender and Wang (2006) and Denis and Sibilkov (2010) find that the value of cash is reduced for less financially constrained firms. Pinkowitz, Stulz, and Williamson (2006) demonstrate how political corruption reduces the marginal value of cash for international firms, although Dittmar and Mahrt-Smith (2007) report that weakened governance reduces the value of cash for US firms. Klasa, Maxwell, and Ortiz-Molina (2009) find the value of cash decreases with increased unionization rates.

3. Our sample has mean cash-to-assets and receivable-to-assets ratios of $13 \%$ and $18 \%$, respectively. 
The paper proceeds as follows. Section I outlines theoretical underpinnings and specifies the model, whereas Section II describes the sample. Section III presents multivariate results and Section IV provides our conclusions.

\section{Theory AND Model}

\section{A. Trade-offs from Extending Trade Credit}

Meltzer (1960) describes trade credit as a means of easing customers' financing frictions. This facilitates increased sales and market share growth for suppliers (Nadiri, 1969). ${ }^{4}$ Empirical evidence supports the redistributional motive. Firms offering financing have excess liquidity (Petersen and Rajan, 1997), and constrained firms demand trade credit (Atanasova, 2007). The main issue of this study is that suppliers may be able to improve firm value via increased revenues and operating cash flows by resolving customers' liquidity constraints.

In addition to resolving financing constraints, trade credit extension is motivated by contracting costs. That is, supplier financing can increase revenue by alleviating informational friction regarding product quality, as Long, Malitz, and Ravid (1993) demonstrated theoretically. Credit periods allow buyers to evaluate product quality before remitting payment, forcing buyers to prove goods are defective before receiving replacements or refunds as negotiating leverage is ceded to sellers after payment. Lee and Stowe (1993) argue that credit terms serve as a product warranty and that the early payment discount compensates for the risk of defective purchases. Emery and Nayar (1998) extend this construct by suggesting that credit terms also result from buyer and seller repair costs. Long et al. (1993) and Ng, Kilhom-Smith, and Smith (1999) present evidence consistent with the contracting cost motive. Using a sample of Belgian firms, Deloof and Jegers (1996) find mixed results regarding this motive.

In addition to stimulating demand, trade credit increases revenue through interest income. Emery (1984) argues that suppliers would extend credit if the implicit rate of return earned on receivables (i.e., forgone discount) exceeds that of the marginal investment. ${ }^{5} \mathrm{Ng}$ et al. (1999) find typical credit terms of 2/10 net 30, implying an effective annual borrowing cost of roughly $44 \%$ for customers forgoing the discount. Thus, trade credit is generally a lucrative investment for suppliers, especially given the reduced risk of customer default as we discuss later in more detail.

Trade credit can also reduce suppliers' costs, providing an operating motive for offering credit to customers. Emery (1987) shows that relaxed credit policy may be optimal for suppliers facing uncertain demand as the costs of carrying inventory or altering plant capacity may exceed that of supplying financing to customers. Evidence for the operating motive is mixed. Long et al. (1993) find receivables and demand uncertainty directly related. Yet survey evidence presented by $\mathrm{Ng}$ et al. (1999) suggests managers do not alter credit policies because of sales volatility, and Deloof and Jegers (1996) find no support for the operating motive in their sample of Belgian firms.

4. Schwartz (1974) suggests suppliers offset market size constraints by financing the growth of the customer base. In addition to enhancing future business, suppliers' interest in the financial health of customers includes costs of nonsalvageable investments in relationships ( $\mathrm{Ng}$ et al., 1999). An example is point-of-sale efforts requiring salespersons to spend a large amount time to secure the account.

5. The yield differential between the return earned on lending to customers and the market rate may be further exacerbated by differences in tax payment timing between buyer and seller (Brick and Fung, 1984). Also, Petersen and Rajan (1994) point out that even assuming late payment, the effective interest rate on trade credit is greater than for typical investment opportunities. 
Although the benefits of extending trade financing can lead to increased market valuations, managers must consider the trade-offs that accompany the relaxation of trade credit policies. Extending financing involves the administrative costs of screening and monitoring customers, bad debt losses, and discounts granted (Kim and Atkins, 1978; Sartoris and Hill, 1981). In addition, carrying receivables on the balance sheet implies a direct financing cost, and delayed payment terms reduce the present value of receivables.

Several aspects of trade credit imply built-in advantages that reduce credit risk and, subsequently, the required yield on lending to customers. For example, suppliers naturally obtain detailed knowledge regarding their customers' input transactions, whereas lenders acquire this information only through costly monitoring (Burkart and Ellingsen, 2004). Also, suppliers can directly observe payment behavior. Failure to exercise the early payment discount option indicates that lower cost alternatives were unavailable to the customer (Smith, 1987). ${ }^{6}$ Cunat (2006) argues that by controlling the supply of intermediate goods that are necessary for the buyers' production processes, suppliers possess a comparative advantage over other lenders in handling nonpayment. Suppliers also possess a comparative advantage in assessing the liquidation value of repossessed goods (Petersen and Rajan, 1997; Longhofer and Santos, 2003). Stronger relationships between suppliers and customers imply high switching costs including learning and transactions costs associated with changing suppliers (Klemperer, 1987; Chevalier and Scharfstein, 1996; Giannetti, Burkart, and Ellingsen, 2008). Finally, Fabbri and Menichini (2010) offer a theoretical model combining supplier information and liquidation advantages, and suggest the costs of extending trade credit are substantially lower than for a similar bank loan. In sum, the unique relationship forged between producers and buyers diminishes the risks of lending to customers, reducing the required yield on loans to customer.

Overall, we hypothesize a direct relation between shareholder wealth and receivables arising from the benefits of lending to customers and the recent theory suggesting the lower cost of extending financing. Further, the expectation of a direct association between returns and trade credit supplied is consistent with the theoretical models presented by Kim and Atkins (1978) and Sartoris and Hill $(1981,1983)$. We state our first hypothesis (H1) below.

H1: The relation between shareholder wealth and receivables is positive.

Although the economic significance of trade receivables is ultimately an empirical question, we expect the value of a marginal dollar in receivables to be lower than that of cash because of the various costs associated with trade credit that do not affect cash. ${ }^{7}$ This expectation is formally stated in the corollary to H1.

H1A: The market value of receivables is lower than that of cash.

\section{B. Product Market Dynamics}

Evidence from the trade credit literature suggests product market dynamics necessitate the extension of trade credit to customers. Accordingly, producers' ability to enhance shareholder wealth through lending to customers may be conditional upon product market forces. We investigate to determine whether the market recognizes specific trade credit motives by conditioning receivables on product market characteristics. Hypotheses and theoretical underpinnings follow.

6. Brennan, Maksimovic, and Zechner (1988) make this point as well. Bias and Gollier (1997) argue the extension of trade credit to the buyer sends a positive signal regarding the buyer's creditworthiness.

7. To be clear, we are not comparing credit to cash terms. This hypothesis simply deals with a comparison of the market value of receivables versus the value of cash held on firms' balance sheets. We thank Janet Kiholm Smith for suggesting this clarification. 
H2: The market value of receivables is an increasing function of demand uncertainty.

With Emery's (1987) operating motive for trade credit, suppliers can reduce the costs of uncertain sales by relaxing credit policy. For example, instead of holding excess inventory or altering plant capacity during periods of unexpectedly reduced demand, firms can ease lending standards or offer more attractive credit terms. This would be an optimal strategy for firms finding receivables cheaper to finance than inventory. Therefore, we expect a higher market value of trade receivables for producers facing less certain demand. We measure demand uncertainty using the coefficient of variation of a firm's annual sales. ${ }^{8}$

H3: The market value of receivables increases with the importance of assessing product quality.

Credit periods can mitigate informational friction regarding product quality by allowing buyers to assess the quality of goods before remitting payment and by providing negotiating leverage if the goods are defective (Long et al., 1993). By reducing informational asymmetries regarding quality, trade credit should improve sales for those firms supplying products that are more difficult to assess.

We proxy for the importance of product quality assessment using reputational capital, industry affiliation, R\&D expenditures, and asset turnover, similar to Long et al. (1993). Firms with less established reputations will have a greater need to use credit terms to signal quality. Our proxy for supplier reputation is market share, calculated as annual firm sales divided by annual industry sales. Firms with higher market share are typically older and well established in their product markets, providing a positive signal regarding product quality to potential buyers. Hence, the benefit of using trade credit to reduce asymmetric information regarding the quality of goods will be smaller for suppliers with larger market shares.

To the extent that market share indicates sellers' overall incentive to stimulate increased sales, it is likely that this variable captures a product market dimension in addition to product quality. Nadiri (1969) and Schwartz (1974) argue that the primary motive for trade credit extension is to improve product marketability, facilitate sales, and to reduce customers' transactions costs (Ferris, 1981) and/ or financing frictions (Meltzer, 1960). Accordingly, lending to customers should create more value for suppliers with smaller market share because they have a greater incentive to increase sales. Irrespective of the product market dimension captured, the benefit of trade credit policy is expected to be a decreasing function of market share.

The nature of the product determines the time needed to assess its quality. For instance, perishable goods are much easier to inspect and assess than technical products. Thus, we follow Giannetti et al. (2008) and classify firms into one of three industry types: 1) services, 2) differentiated goods, and 3) standardized goods. ${ }^{9}$ We expect receivables held by firms producing differentiated goods to create more value, relative to the other industry classifications. As discussed by Giannetti et al.

8. Sales volatility is measured as the standard deviation of a firm's annual sales divided by the firm's mean annual sales. The standard deviation of sales is calculated over a rolling five-year period before each of the sample years. For example, the standard deviation of sales for 2006 is calculated over the five-year from 2001 to 2005. Firm-year observations are included in the sample for a given year if the firm has at least three observations during the previous five-year period. Thus, sales volatility is designed as a backward looking measure. The mean level of sales is estimated over the same five-year period. Hill, Kelly, and Highfield (2010) estimate sales volatility similarly.

9. Giannetti et al.'s (2008) classification scheme builds from Rauch (1999) in which industries are categorized by the first two digits of two-digit standard industrial classification (SIC) code. Services include 41, 42, 44, 45, 47-57, 59, 61, 64, 65, 73, 75, 78, and 79. Differentiated include 25, 27, 30, 32, 34-39. Standardized include 12, 14, 20, 22-24, 26, 28, 29, 31, and 33. This scheme does not cover our entire sample firm's SIC codes (12,153 observations). In lieu of limiting the sample and potentially 
(2008), the nature of the transacted good determines the costs of switching suppliers and the liquidation value, which influences buyers' default risk. From this perspective, trade credit offered by firms selling differentiated products is less risky than for other producers. Consequently, both the product quality and control advantage theories predict an increased market value of trade credit for producers selling differentiated products. These views are not mutually exclusive.

Other variables associated with the nature of the produced goods include R\&D expenditures and the length of the production cycle. Deloof and Jegers (1996) argue that firms with greater R\&D expenses produce high-tech goods for which product quality is difficult to determine. Long et al. (1993) argue that production cycle length proxies for the time needed to assess product quality. Products with longer production cycles are likely more detailed and less homogeneous. We measure the length of the production cycle using total asset turnover, defined as sales divided by net assets. Thus, the value of trade receivables may vary with R\&D expenses and production cycle time.

\section{Financial Constraint}

The ability of sellers to increase firm value by financing sales should depend on suppliers' degree of financial constraint. Relative to financially unconstrained firms, constrained firms have limited access to capital and face more costly external financing, making them more likely to forgo otherwise attractive project opportunities (Almeida, Campello, and Weisbach, 2004).

In terms of trade credit policies, the nontrivial costs of extending trade credit make it more difficult for constrained firms to use supplier financing strategically to increase market share and firm value. That is, financially constrained suppliers might forgo sales that are contingent upon the customer's receipt of seller financing (Nadiri, 1969). Consistent with this intuition, Calomiris, Himmelberg, and Wachtel (1995) report that receivables are directly related to commercial paper issuance. Petersen and Rajan (1997) find trade credit is positively associated with credit line availability. In addition, Molina and Preve (2009) confirm that firms in financial distress extend significantly less trade credit. Given constrained firms' higher marginal financing costs and limited ability to externally finance receivables, equity markets may prefer these firms to preserve cash for project or R\&D opportunities, instead of funding inventory and receivables. If this is the case, then we would expect to observe a discounted value of receivables for constrained firms.

The market value of supplier financing will also reflect the liquid nature of receivables, leading to an alternative expectation for the effect of financial constraint on the value of trade receivables. Increased receivables reveal implicit information about future cash flows. An extra dollar in current period receivables leads to increased cash holdings in the future, ignoring collection losses. Receivables also provide flexibility as they can be collateralized and used to secure funding through assetbacked financing channels. Furthermore, if funds are needed before collection, receivables can be factored (Mian and Smith, 1992). Because unconstrained firms can access capital markets for speculative or precautionary purposes, the liquidity source of value for receivables will be lower for unconstrained firms. Supporting this, Faulkender and Wang (2006) and Denis and Sibilkov (2010) find the value of an additional dollar in cash holdings to be significantly lower for unconstrained firms relative to constrained firms. Thus, if equity investors view receivables as a near substitute for cash, then the value of receivables should increase with the degree of financial constraint.

creating a sample selection bias, unclassified firms are categorized as Standardized. Nonetheless, we find identical results after limiting the sample. Also, we examine the sensitivity of our results to alternative industry definitions. 
Overall, the literature supports competing hypotheses regarding the impact of financial constraint on the value of trade receivables. Accordingly, we state $\mathrm{H} 4$ in terms of the null hypothesis:

H4: The market value of receivables is unrelated to financial constraint.

To test this hypothesis, we follow the recent literature and measure financial constraint using the payout ratio, firm size, and long-term bond and commercial paper ratings. Variable definitions follow those in Almeida et al. (2004), Faulkender and Wang (2006), and Denis and Sibilkov (2010) as described below.

1) Payout ratio: The payout ratio is the sum of common dividends and repurchases divided by earnings. For each sample year, we sort firms by annual payout ratios and assign to the constrained (unconstrained) group those firms whose ratios are less (greater) than or equal to the payout ratio of the firm at the 30th (70th) percentile of the payout ratio distribution for each year. The rationale for this approach is that firms with high payouts have cash flows sufficient to service debt obligations and to finance investment (Fazzari, Hubbard, and Petersen, 1988). Further, dividends can be cut to preserve cash.

2) Firm size: For each year in the sample, we rank all firms by their sales at the end of the previous fiscal year. Firms with sales less (greater) than or equal to the sales in the bottom (top) three deciles of the annual size distribution are classified as constrained (unconstrained). Larger firms are generally older with reduced informational asymmetries and enhanced access to public and private capital markets.

3) Long-term bond rating: Using bond ratings provided by Compustat, we assign firmyears with bond ratings and positive debt levels to the unconstrained group. Observations without bond ratings, but with positive debt levels are classified as constrained. The underlying intuition is that firms with bond ratings have superior access to debt and at lower marginal transactions costs. Therefore, rated firms should be less reliant on internal financing.

4) Commercial paper rating: The constraint categorization for commercial paper ratings follows the bond rating intuition. As Faulkender and Wang (2006) note, firms with rated commercial paper are considered least likely financially constrained among publicly traded firms using debt.

Because of space constraints, we create the dummy variables $U C 2 \_D V$ and $U C 3 \_D V$, which denote whether the firm-year observation is constrained for at least two or three, respectively, of the aforementioned financial constraint criteria. The indicator variables equal one if the firm-year is classified as unconstrained, and zero otherwise.

In addition to the financial constraint dummies, we also examine the impact of prior period cash holdings on the value of receivables. By accounting for internal financial flexibility, we recognize that although strong capital market access is one way to manage cash flow uncertainty, cash holdings can insulate firms from costly external financing when cash flow shortfalls occur (Opler et al., 1999). Accordingly, firms with greater prior period cash holdings possess a stronger ability to finance trade receivables internally. Alternatively, equity markets may view receivables solely as near-term cash and discount the former. From this perspective, the value of receivables should decrease with prior period cash levels, similar to Faulkender and Wang's (2006) finding that the value of a marginal dollar in cash decreases with prior period cash holdings. 
Molina and Preve (2009) find that over levered firms in financial distress extend significantly less trade credit. Following this intuition, the expected impact of leverage on the value of receivables is unambiguous. The value of an additional receivable should decrease with leverage. As leverage increases, the additional dollar generated by increased receivables is more likely captured by debt holders via increased debt service requirements or increased debt values. Faulkender and Wang's (2006) finding that the value of cash decreases with leverage supports this view. Also, over levered firms will find it more difficult and expensive to extend trade credit. No matter which view dominates, we expect equity holders to discount the value of receivables for firms with greater leverage, leading to $\mathrm{H} 5$ :

H5: The market value of receivables decreases with leverage.

\section{Model}

We adjust the valuation approach of Faulkender and Wang (2006) to estimate the relationship between equity values and trade receivables. The model regresses annual excess stock returns on unexpected changes in financial characteristics. Regression estimates yield shareholders' capitalization of changes in these characteristics, so the model resembles a long-term event study. Variables and data definitions are identical to those of Faulkender and Wang (2006), although our focus on receivables leads us to control for additional factors that might correlate with the change in receivables and stock returns. Our base model follows:

$$
\begin{aligned}
r_{i, t}-R_{i, t}^{B}=r_{0} & +r_{1} \frac{\Delta C_{i, t}}{M V E_{i, t-1}}+r_{2} \frac{\Delta T R_{i, t}}{M V E_{i, t-1}}+r_{3} \frac{\Delta E_{i, t}}{M V E_{i, t-1}}+r_{4} \frac{\Delta N A_{i, t}}{M V E_{i, t-1}} \\
& +r_{5} \frac{\Delta R \mathcal{E} D_{i, t}}{M V E_{i, t-1}}+r_{6} \frac{\Delta E_{i, t}}{M V E_{i, t-1}}+r_{7} \frac{\Delta D_{i, t}}{M V E_{i, t-1}}+r_{8} L e v_{i, t} \\
& +r_{9} \frac{N F_{i, t}}{M V E_{i, t-1}}+r_{10} \text { SalesG }+ \text { FirmandTimeEffects }+\varepsilon_{i, t}
\end{aligned}
$$

where $\Delta X$ represents a change in $X$ from year $t-1$ to $t$.

Our dependent variable is the firm's annual excess stock return defined as the firm's annual raw returns $\left(r_{i, t}\right)$ minus the expected return $\left(R^{B}\right)$. The raw return is equal to the change in the market value of equity plus dividends divided by the lagged market equity, where these variables are collected from Center for Research in Security Prices. Benchmark returns are taken from Fama and French (1993) $5 \times 5$ size and book-to-market portfolio sorts. ${ }^{10}$ The portfolios are formed at the end of June in year $t$. The size sort uses the firm's market value of equity as of the end of June in year $t$, whereas the book-to-market sort uses the ratio of book value of equity at fiscal year-end in calendar year $t-1$ and market equity at the end of December in calendar year $t-1$.

As our goal is to measure value implications attributable to changes in a firm's supply of trade credit, it is necessary to control for other changes in financial characteristics. Following Faulkender and Wang (2006), we account for changes in profitability, investment, and financing policy. Earnings before extraordinary items $(E)$ proxies for profitability. ${ }^{11}$ Regressors accounting for investment

10. We thank Ken French for providing data on the book-to-market and size portfolio breakpoints and returns via his data library website: http://mba.tuck.dartmouth.edu/pages/faculty/ken.french/data_library.html .

11. Compustat variable names and our calculations follow. The market value of equity, MVE, is the number of shares (CSHPRI:54) multiplied by the share price at fiscal year-end (PRCC_F:199). TC is trade receivables (RECTR:151). C is cash and marketable securities (CHE:1). E is earnings before extraordinary items (IB:18) plus interest expense (XINT:15), deferred 
include $R \& D$ expense $(R \mathcal{E} D)$ and net assets $(N A)$, calculated as total assets minus cash and receivables. Controls for financial policy include cash $(C)$, interest expense $(I)$, dividends $(D)$, market leverage $(L)$, and net financing $(N F)$. Interest expense, market leverage, and net financing control for different aspects of financing policy. The market leverage ratio accounts for the firm's overall debt load, net financing captures the net impact of debt/equity issuances and repurchases, and interest expense accounts for the costs of debt. We depart from Faulkender and Wang (2006) by including sales growth (Sales $G$ ) as a regressor as the change in receivables is likely correlated with sales growth, which could otherwise lead to omitted variables bias. ${ }^{12}$ Equation (1) also controls for fixed time and firm effects. Because $r_{i, t}$ and most of the regressors are scaled by the lagged market value of equity $\left(M V E_{t-1}\right)$, the coefficient estimates represent the additional value to shareholders because of a $\$ 1$ increase in the regressor. ${ }^{13}$

The variable of interest is $\Delta T R$ defined as the change in trade receivables scaled by the lagged market value of equity. ${ }^{14}$ Our receivables measure consists solely of trade receivables, isolating the effects of supplier financing on equity value after accounting for other financial characteristics known to influence excess returns. Thus, $\gamma_{2}$ represents the market value of an unexpected additional dollar held in trade receivables, providing the equity market's assessment of the joint impact of the costs and benefits associated with supplier financing. A positive and significant $\gamma_{2}$ indicates investors update their valuations based on unexpected changes in receivables.

We determine the marginal effect of product market dynamics and financial constraint on the market value of trade receivables by including interactions between the receivables ratio and firm characteristics $\left(\Delta T R^{*}\right.$ ProdMktVar and $\Delta T R{ }^{*}$ FinConstVar) in Equation (1). The interaction terms represent the premium or discount associated with the market value of trade receivables after conditioning on a given characteristic.

\section{Data Source And Description}

The initial sample includes all nonfinancial, nonutility, non-American depositary receipt, and standard industrial classification (SIC)-classifiable firms covered by Compustat from 1971 to 2006. We eliminate firm-years missing the required financial data, those having nonpositive values for the market value of equity and net assets, and observations with negative dividends. Using the change

tax credits (TXDI:50), and investment tax credits (ITCI:51). RD is research and development expenditures (XRD:46). NA is net assets defined as total assets (AT:6) minus cash and receivables. $I$ is interest expense. $D$ is common dividends paid (DVC:21). L is market leverage defined as long-term debt (DLC:34) plus debt in current liabilities (DLTT:9) divided by the sum of the market value of equity, long-term debt, and debt in current liabilities. NF is net financing calculated as equity issuance (SSTK:108) minus repurchases (PRSTKC:115) plus debt issuance (DLTIS:111) minus debt redemption (DLTR:114). Sales $G$ is calculated as the percentage change in net sales (SALE:12). Like Faulkender and Wang (2006), we set the variables deferred tax credits (TXDI:50), investment tax credits (ITCI:51), and research and development expenditures (XRD:46) equal to zero if missing.

12. We thank Lorenzo Preve for suggesting this control, and for his suggestion to examine the value of trade credit across industry competitiveness. We also thank an anonymous reviewer for suggesting we examine the influence of financial constraint on the value of trade credit.

13. The marginal effect of trade receivables on firm value is calculated by taking the partial derivative of Equation (1) with respect to the change in receivables. Because the denominator of both sides of the differentiated equation is the lagged market value of equity, the incremental change in value attributable to a $\$ 1$ increase in trade receivables is $\gamma_{2}$. With fixed firm effects modeled, the differenced variables capture the change in a variable relative to the average change in that variable over the firm's panel.

14. For ease of presentation, we suppress the scaling of the regressors for the remainder of the paper. For example, $\Delta T R$ refers to the ratio $\triangle T R_{i, t} / M V E_{i, t-1}$. 


\section{Table I. Descriptive Statistics}

This table reports the sample characteristics of 75,800 observations for 10,648 unique firms from 1973 to 2006. Variables are reported in decimal form. $\Delta X$ represents the one-year change in $X, X_{t}-X_{t-1}$. Except for $L$ and SalesG, all variables are scaled by the lagged market value of equity. ExcessRet is excess return, where the Fama and French (1993) size and book-to-market portfolio matched return is used as the benchmark portfolio. $C$ is cash and marketable securities. $T R$ is trade receivables. $E$ is earnings defined as earnings before extraordinary items. $N A$ is net assets (total assets minus cash and receivables). $R D$ is research and development expenditures. $l$ is interest expense. $D$ is common dividends. $L$ is the market leverage ratio. $N F$ is net new financing. Sales $G$ is the percentage change in sales. CV_Sales is the coefficient of variation for annual sales. MktShare is firm sales divided by aggregate industry sales in a given year. DiffProd is an indicator variable equal to one if the firm produces differentiated products, and zero otherwise. Services is an indicator variable equal to one if the firm is a service provider, and zero otherwise. StandProd is an indicator variable equal to one if the firm produces standardized products, and zero otherwise. SIC classifications used to identify DiffProd, StandardProd, and Services follow Giannetti et al. (2008). Turnover is asset turnover defined as sales divided by total assets minus receivables. UC2_DV (UC3_DV) is an indicator variable set to one if the observation is deemed financially constrained by at least two (three) financial constraint criteria, and zero otherwise.

\begin{tabular}{|c|c|c|c|c|}
\hline Variables & $N$ & Mean & Median & $S D$ \\
\hline ExcessRet $_{i, t}$ & 75,800 & -0.007 & -0.085 & 0.555 \\
\hline$\Delta C_{i, t}$ & 75,800 & 0.006 & 0.000 & 0.122 \\
\hline$\Delta T R_{i, t}$ & 75,800 & 0.011 & 0.005 & 0.111 \\
\hline$\Delta E_{i, t}$ & 75,800 & 0.009 & 0.006 & 0.165 \\
\hline$\Delta N A_{i, t}$ & 75,800 & 0.031 & 0.018 & 0.326 \\
\hline$\Delta R D_{i, t}$ & 75,800 & 0.001 & 0.000 & 0.016 \\
\hline$\Delta l_{i, t}$ & 75,800 & 0.001 & 0.000 & 0.024 \\
\hline$\Delta D_{i, t}$ & 75,800 & 0.000 & 0.000 & 0.006 \\
\hline$L_{i, t}$ & 75,800 & 0.248 & 0.200 & 0.220 \\
\hline$N F_{i, t}$ & 75,800 & 0.038 & 0.001 & 0.193 \\
\hline SalesG $G_{i, t}$ & 75,800 & 0.118 & 0.052 & 0.417 \\
\hline CV_Sales ${ }_{i, t}$ & 59,627 & 0.230 & 0.165 & 0.210 \\
\hline MktShare $_{i, t}$ & 75,800 & 0.016 & 0.002 & 0.052 \\
\hline DiffProd $_{i, t}$ & 75,800 & 0.373 & 0.000 & 0.484 \\
\hline Services $_{i, t}$ & 75,800 & 0.268 & 0.000 & 0.443 \\
\hline StandProd $_{i, t}$ & 75,800 & 0.217 & 0.000 & 0.412 \\
\hline Turnover $_{i, t}$ & 75,800 & 1.768 & 1.498 & 1.521 \\
\hline$U C 2 \_D V_{i, t}$ & 75,800 & 0.268 & 0.000 & 0.443 \\
\hline UC3_DV $V_{i, t}$ & 75,800 & 0.110 & 0.000 & 0.313 \\
\hline$C_{i, t-1}$ & 75,800 & 0.153 & 0.086 & 0.210 \\
\hline
\end{tabular}

in variables sacrifices the first observation for each firm. We winsorize both tails of the ratios at the $1 \%$ level. The final sample is an unbalanced panel of 75,800 firm-year observations for 10,648 companies from 1973 to $2006 .^{15}$

Table I displays sample descriptive statistics. The mean change in trade receivables as a percentage of the lagged market value of equity $(\Delta T R)$ is $1 \%$, and the variable displays substantial variation with a standard deviation of $11 \%$. The remaining variables are similar in sign and magnitude

15. Compustat's initial coverage of trade receivables is weaker than for total receivables, which is why the sample period begins in 1973 even though our data extends to 1971. Further, because of the initially weak coverage of the trade receivables variable, only 15 observations occur from 1973 to 1975. Rather than drop these observations, we fold them into the base year (1976). 
to those reported by Faulkender and Wang (2006). Restrictions necessary to calculate a meaningful measure of demand uncertainty (CV_Sales) reduce the number of observations for this variable. Univariate statistics indicate that the majority of sample firms produce differentiated products, followed by service providers and producers of standardized products. Twenty-two percent of observations are classified as financially unconstrained based on at least two (UC2_DV) of the constraint criteria. ${ }^{16}$

\section{RESULTS}

\section{A. Baseline Results}

The remaining tables present results after estimating versions of Equation (1). We control for firm fixed effects to alleviate any potential correlation between changes in trade credit and unobserved heterogeneity that may also influence shareholder wealth. ${ }^{17}$ Standard errors are robust to heteroskedasticity and within-firm correlation (Petersen, 2009).

Statistical inferences for the control variables are identical to those of Faulkender and Wang (2006) and Denis and Sibilikov (2010). Column 1 of Table II results suggest a $\$ 0.62$ marginal value of cash. Not surprisingly, the equity market reacts favorably to surprises in earnings and dividends. Results also indicate a significant and direct relationship between excess returns and changes in investment $(\triangle N A$ and $\triangle R D)$. A positive association exists between equity values and net issuance of securities. We also find that lower excess returns follow increase in interest expense and leverage. ${ }^{18}$ Sales growth and excess returns are positively and significantly related. Overall, the results for the controls are consistent with our expectations and previous studies.

The estimate of interest is $\gamma_{2}$ capturing the equity market's assessment of the trade-offs and subsequent net benefit associated with supplier financing. The results in column 1 support H1 and indicate that shareholder wealth is directly and significantly related to trade credit supplied even after controlling for other financial characteristics that are likely to impact equity values. The positive and significant value-receivables relation is consistent with the expectation of market share gains and the accompanying future liquidity provided by receivables. Initial findings support theoretical models (Kim and Atkins, 1978; Sartoris and Hill $(1981,1983)$ illustrating trade credit policy's impact on firm value, thereby providing a market value explanation for the existence and prevalence of this shortterm operating asset. Suppliers extend credit because it increases shareholder wealth, on average.

With respect to the market value of trade receivables, the estimate for $\gamma_{2}$ suggests an additional dollar in financing provided to customers increases shareholder wealth by roughly $\$ 0.50$. The estimated marginal value of cash is $\$ 0.12$ greater than that of receivables, an economically and statistically significant (at the 1\% level) difference that supports H1A. This result is consistent with the costs of carrying receivables (financing and opportunity costs, discounted payments, and collection losses) exceeding those of cash.

16. Untabulated Pearson correlation coefficients show a positive and significant correlation between excess returns and trade receivables, which is preliminary support for $\mathrm{H} 1$.

17. Hausman's (1978) test statistic suggests fixed effects are preferred to random effects for our sample. Random effects results are similar economically and have unchanged significance levels. Also, inferences are unchanged after reestimating Equation (1) using ordinary least squares (OLS) with Newey-West (1987) standard errors that account for both autocorrelation and heteroskedasticity.

18. Unreported variance inflation factors suggest multicollinearity is not an issue for our data set or model. Estimations of parsimonious versions of Equation (1) indicate that excess returns are directly and significantly related to trade receivables, our variable of interest. We thank an anonymous reviewer for suggesting these additional tests. 


\section{Table II. Market Value of Trade Receivables}

This table presents fixed effects regressions estimating the market value of receivables per Equation (1). The full sample consists of 75,800 observations for 10,648 unique firms from 1973 to 2006 . The dependent variable is excess returns, where the Fama and French (1993) size and book-to-market portfolio matched return is used as the benchmark portfolio. $\Delta X_{t}$ represents the one-year change in $X\left(X_{t}-X_{t-1}\right)$. Variables other than $L$ and Sales $G$ are scaled by the lagged market value of equity. $C$ is cash and marketable securities. TR is trade receivables. $E$ is earnings defined as earnings before extraordinary items. NA is net assets calculated as total assets minus cash and receivables. $R D$ is research and development expenditures. $I$ is interest expense. $D$ is common dividends. $L$ is the market leverage ratio. $N F$ is net new financing. Sales $G$ is the percentage change in sales. NTC is trade receivables minus trade payables. IndAdj $\triangle T R$ is $\triangle T R$ minus the annual industry median of $\triangle T R$. Observations used for the results in column 3 (column 4) consist of concentrated (competitive) industries defined as industries with Herfindahl index values exceeding (not exceeding) the sample median annual Herfindahl index. IndAdj $\triangle T R$ and Herfindahl index calculations use Fama and French (1997) industry classifications. F-test results indicate differences in estimates for $\triangle T R$ across the concentrated and competitive subsamples. Models include time dummy variables. Unreported standard errors are robust to heteroskedasticity and cluster at the firm level. $t$-statistics appear in parentheses. Intercepts are omitted because of space constraints.

\begin{tabular}{|c|c|c|c|c|c|}
\hline $\begin{array}{l}\text { Independent } \\
\text { Variables }\end{array}$ & (1) & (2) & (3) & (4) & (5) \\
\hline$\overline{\Delta C_{i, t}}$ & $\begin{array}{c}0.624^{* * *} \\
(24.272)\end{array}$ & $\begin{array}{l}0.659^{* * *} \\
(17.270)\end{array}$ & $\begin{array}{l}0.583^{* * *} \\
(15.325)\end{array}$ & $\begin{array}{c}0.621^{\text {***}} \\
(23.895)\end{array}$ & $\begin{array}{l}0.623^{\text {** }} \\
(24.198)\end{array}$ \\
\hline$\Delta T R_{i, t}$ & $\begin{array}{l}0.504^{\star \star \star} \\
(17.669)\end{array}$ & $\begin{array}{l}0.536^{\star \star \star} \\
(11.526)\end{array}$ & $\begin{array}{l}0.476^{\star \star *} \\
(12.493)\end{array}$ & $\begin{array}{l}- \\
-\end{array}$ & $\begin{array}{l}- \\
-\end{array}$ \\
\hline$\Delta E_{i, t}$ & $\begin{array}{l}0.650^{* * *} \\
(33.605)\end{array}$ & $\begin{array}{l}0.638^{* * *} \\
(22.879)\end{array}$ & $\begin{array}{l}0.655^{\star \star *} \\
(22.675)\end{array}$ & $\begin{array}{l}0.670^{* * *} \\
(33.993)\end{array}$ & $\begin{array}{l}0.654^{\text {*** }} \\
(33.787)\end{array}$ \\
\hline$\Delta N A_{i, t}$ & $\begin{array}{l}0.074^{* * *} \\
(6.567)\end{array}$ & $\begin{array}{l}0.097^{\star * *} \\
(5.686)\end{array}$ & $\begin{array}{l}0.061^{* * *} \\
(3.729)\end{array}$ & $\begin{array}{c}0.120^{* * *} \\
(10.426)\end{array}$ & $\begin{array}{l}0.075^{\star \star *} \\
(6.695)\end{array}$ \\
\hline$\Delta R D_{i, t}$ & $\begin{array}{l}0.517^{* * *} \\
(2.637)\end{array}$ & $\begin{array}{c}0.310 \\
(1.161)\end{array}$ & $\begin{array}{c}0.494^{*} \\
(1.684)\end{array}$ & $\begin{array}{l}0.616^{* * *} \\
(3.124)\end{array}$ & $\begin{array}{l}0.529^{* * *} \\
(2.696)\end{array}$ \\
\hline$\Delta l_{i, t}$ & $\begin{array}{l}-1.723^{\star * *} \\
(-13.458)\end{array}$ & $\begin{array}{l}-1.944^{* * *} \\
(-9.150)\end{array}$ & $\begin{array}{l}-1.454^{* * *} \\
(-8.422)\end{array}$ & $\begin{array}{l}-1.741^{* * *} \\
(-13.566)\end{array}$ & $\begin{array}{l}-1.723^{\text {*** }} \\
(-13.459)\end{array}$ \\
\hline$\Delta D_{i, t}$ & $\begin{array}{l}1.028^{* * *} \\
(3.373)\end{array}$ & $\begin{array}{c}0.476 \\
(0.956)\end{array}$ & $\begin{array}{l}1.213^{* * *} \\
(2.863)\end{array}$ & $\begin{array}{l}1.122^{* * *} \\
(3.674)\end{array}$ & $\begin{array}{l}1.049^{* \star *} \\
(3.444)\end{array}$ \\
\hline$L_{i, t}$ & $\begin{array}{l}-1.068^{* \star *} \\
(-57.108)\end{array}$ & $\begin{array}{l}-1.095^{\star * \star} \\
(-38.751)\end{array}$ & $\begin{array}{l}-1.093^{* * *} \\
(-38.103)\end{array}$ & $\begin{array}{l}-1.074^{* * *} \\
(-57.039)\end{array}$ & $\begin{array}{l}-1.070^{* * *} \\
(-57.144)\end{array}$ \\
\hline$N F_{i, t}$ & $\begin{array}{l}0.134^{* * *} \\
(7.149)\end{array}$ & $\begin{array}{l}0.107^{* * *} \\
(3.788)\end{array}$ & $\begin{array}{l}0.129^{* * *} \\
(4.685)\end{array}$ & $\begin{array}{l}0.140^{* * *} \\
(7.367)\end{array}$ & $\begin{array}{l}0.137^{* * *} \\
(7.272)\end{array}$ \\
\hline Sales $G_{i, t}$ & $\begin{array}{l}0.089^{* * *} \\
(10.094)\end{array}$ & $\begin{array}{l}0.097^{* * *} \\
(7.367)\end{array}$ & $\begin{array}{l}0.088^{* * *} \\
(6.793)\end{array}$ & $\begin{array}{l}0.108^{* * *} \\
(12.126)\end{array}$ & $\begin{array}{l}0.091^{\text {*** }} \\
(10.306)\end{array}$ \\
\hline$\Delta N T C_{i, t}$ & - & $\begin{array}{l}- \\
-\end{array}$ & $\begin{array}{l}- \\
-\end{array}$ & $\begin{array}{l}0.232^{* * *} \\
(8.772)\end{array}$ & $\begin{array}{l}- \\
-\end{array}$ \\
\hline IndAdj $\Delta T R_{i, t}$ & $\begin{array}{l}- \\
-\end{array}$ & - & $\begin{array}{l}- \\
-\end{array}$ & $\begin{array}{l}- \\
-\end{array}$ & $\begin{array}{l}0.485^{\text {*** }} \\
(16.982)\end{array}$ \\
\hline $\begin{array}{l}F \text {-test for difference } \\
\text { in } \Delta T R \text { ( } p \text {-value) }\end{array}$ & - & - & $\begin{array}{l}2.490 \\
(0.115)\end{array}$ & - & - \\
\hline Fixed effects & Firm and time & Firm and time & Firm and time & Firm and time & Firm and time \\
\hline Sample & Full & Concentrated & Competitive & Full & Full \\
\hline Observations & 75,800 & 36,533 & 39,267 & 75,800 & 75,800 \\
\hline$R^{2}$ & 0.200 & 0.213 & 0.197 & 0.194 & 0.200 \\
\hline
\end{tabular}

*** Significant at the 0.01 level.

* Significant at the 0.10 level. 
Next, we examine differences in the value of receivables across concentrated and competitive industries. The rationale behind this test is that the degree of market concentration within an industry may influence the negotiating leverage of suppliers and, therefore, their ability to dictate terms to customers (Hill, Kelly, and Highfield, 2010). Specifically, suppliers in concentrated industries are better positioned to offer more stringent credit terms (i.e., shorter credit periods or reduced discounts), possibly implying an increased value of trade receivables. Also, increased concentration may reduce the risk of lending to customers as customer defaults would be less frequent because of fewer potential replacement suppliers and higher switching costs (Klemperer, 1987; Chevalier and Scharfstein, 1996). At the same time, the operating characteristics of concentrated industries may reduce the need for trade credit extension. Molina and Preve (2009) find that the negative effect of financial distress on receivables levels is most pronounced for firms in concentrated industries, demonstrating the impact of industry competition on trade credit policy.

Columns 2 and 3 present our results after splitting the sample into concentrated and competitive industries and estimating Equation (1). We follow Molina and Preve (2009) and define an industry to be concentrated if its Herfindahl index exceeds the median for the year, and competitive otherwise. The last entry in column 3 provides $F$-test results for differences in $\gamma_{2}$ across the subsamples. The difference in the market value of receivables across subsamples is insignificantly different from zero, which may result from the offsetting costs and benefits of trade credit for firms in concentrated industries.

In the remaining Table II results, we re-estimate the baseline model using alternative measures of trade receivables to address a potential errors-in-variables problem associated with our proxy for receivables. One measurement issue is that receivables may proxy the suppliers' ability to finance their own purchases, in addition to capturing their willingness to lend to customers. This concern stems from Burkart and Ellingsen's (2004) argument that firms tend to simultaneously supply and demand trade credit, as well as empirical evidence indicating that suppliers finance receivables with payables (Atanasova, 2007; Molina and Preve, 2009). Thus, we replace $\Delta T R$ with the change in net trade credit (receivables minus payables) scaled by the lagged market value of equity $(\triangle N T C)$. The results in column 4 suggest a positive and significant relation between excess returns and firms' net investment in trade credit. Moreover, the estimated market value of an additional dollar in net trade credit $(\$ 0.23)$ is less than for an additional dollar in receivables, as expected given the variable construction.

Next, we measure trade credit using the industry-adjusted receivables ratio, reflecting the influence of industry norms on operating working capital behavior (Hawawini, Viallet, and Vora, 1986). We remove the component of receivables attributable to industry affiliation by subtracting the annual industry median change in receivables ratio from $\Delta T R$. Our initial estimate of the marginal value of trade receivables is robust to this substitution as trade credit extended in excess of that offered by industry peers appears to increase shareholder wealth. Economic interpretations are unchanged, relative to evidence in column 1.

In untabulated results that are available by request, we further examine the robustness of the original findings to alternative measures of trade receivables. Specifically, we replace trade receivables with total accounts receivable (Compustat variable RECT: A2). This definition of receivables represents all claims collectible within the year including trade credit granted to customers, income tax refunds, and dividends receivable, among others. Similar to the baseline results, we find a direct and significant relationship between excess returns and this receivables measure. The coefficient estimate is smaller, possibly indicating that the original definition is a less noisy proxy for supplier financing.

Not all firms use the same fiscal year for their financial statements, possibly introducing arbitrary differences in observed trade credit behavior. In addition, seasonality effects across industries may 
cause receivables levels to fluctuate dramatically during the course of a year making annual receivables a noisy proxy for daily trade credit levels. Tourism and toy industries are common examples of these (Preve and Sarria-Allende, 2010). Subsequently, we replace annual receivables with the quarterly average, smoothing variations in trade receivables attributable to differences in fiscal year-ends or operating cycles. ${ }^{19}$ This lowers the market value of receivables estimate, which may be attributable to information leakage associated with quarterly announcements of changes in receivables, thereby reducing information associated with the unexpected annual change in receivables. Despite the reduction in economic significance, the primary implications and inferences are preserved. The quarterly change in receivables ratio is positive and significant at the $1 \%$ level.

\section{B. Additional Robustness Tests}

In additional untabulated tests, we examine the robustness of the initial findings to dependent variable specification, scale factor, and overall model framework. After replacing excess returns with unadjusted raw returns, our results indicate a direct and significant association between shareholder wealth and trade credit supplied. Using either book value of net assets or book value of equity as the scale factor for the independent variables, we consistently find positive and significant relations between excess returns and trade receivables. So, although the interpretations and economic significance of the coefficients differ across scale factors, firm value and trade receivables are still directly and significantly related. We also examine the value of receivables using adjusted Fama and French (1998) value regressions and find that firm value is directly and significantly related to trade receivables. Thus, we conclude that our initial results are robust to an alternative framework. ${ }^{20}$

The specification of our valuation framework assumes a constant marginal value of receivables over time, which may be an inappropriate assumption for a panel of this length. We investigate the variation in the value of receivables over time using subsequent versions of Equation (1). First, we estimate the model for separate decades and find a lower market value of receivables in the 1970s, relative to later decades. In addition, after splitting the sample into five-year subperiods, our results suggest the marginal value of receivables increases nonmonotonically over the last half of the sample period. In fact, the value of receivables is $\$ 0.26$ during the first subperiod, but increases to $\$ 0.63$ over the last subperiod. This value differential is statistically significant ( $p$-value $=0.001) \cdot{ }^{21}$ Finally, we estimate Fama and MacBeth (1973) regressions via ordinary least squares (OLS) and average the time-series of the coefficient estimates for $\gamma_{2}$. Again, we observe an increasing value of receivables. The annual mean value of $\gamma_{2}$ equals $\$ 0.56$, and is significantly different from zero (1\% level). In only one of the annual regressions is the market value of trade receivables statistically insignificant.

19. For firms with less than two quarters of receivables data, we set the quarterly averaged receivables equal to the annual receivables, preserving the sample size.

20. Coefficient estimates obtained from the adjusted Fama and French (1998) method differ in magnitudes from those estimated using the Faulkender and Wang (2006) model. This is because of the alternative framework: 1) seeking to explain cross-sectional variation in the levels of the market-to-book ratio of assets, although Faulkender and Wang (2006) specify excess stock returns as the dependent variable and 2) scaling variables by book assets. We focus on the Faulkender and Wang (2006) methodology as the authors point out that their method is an improvement over the market-to-book regression because: 1) excess returns account for variation in risk factors (i.e., discount rates and/or risk premia) over time, 2) excess returns are easier interpret, and 3) part of the variation in the market-to-book ratios is because of the cross-sectional variation in accounting methods for book values relative to true replacement costs.

21. In addition, we re-estimated Equation (1) after combining the first and last five-year subperiods. Our results suggest a positive and significant market value of trade receivables (\$0.43). We thank an anonymous reviewer for suggesting that we search for regime shifts in the panel that might identify changes in the value of receivables. 
These findings suggest that the market value of receivables increases over the sample period. This is consistent with higher inflation rates prevailing in the earlier years of the sample period reducing the benefit of suppliers allowing their customers to delay payments (Ben-Horim and Levy, 1983). Also, the increased value of $\gamma_{2}$ over time is consistent with technological advances providing efficiencies in monitoring and collecting on accounts (Maness and Zietlow, 2003). Another possible explanation for our findings may be attributable to reduced financing costs. For example, securitization provides suppliers with an alternative method to manage receivables, possibly reducing the cost of extending/carrying trade credit. Thus, we re-estimate Equation (1) before and after 1985, roughly the time at which firms began to securitize trade receivables (Katz and Blatt, 2008). The value of receivables increases significantly after 1985 (\$0.35 presecuritization and \$0.57 thereafter). This is consistent with the reduction of financing costs in the advent of securitization accompanying the extension of supplier financing. The lack of fine detail in the data precludes a better study of the direct link between suppliers and specific receivers of trade credit that may also contribute to the variation over time in the value of supplier financing. ${ }^{22}$ Although we find that the economic implications of extending trade credit vary through time, we emphasize the consistent positive and significant impact on shareholder wealth (throughout the sample period) associated with providing trade financing to customers.

Overall, our results are robust to firm and time effects, alternative measures of receivables, and econometric specifications. ${ }^{23}$ Further, our variant of Faulkender and Wang's (2006) model provides a strong empirical framework for estimating the shareholder wealth effects of extending credit to customers.

\section{Product Market Dynamics}

Our results suggesting a direct excess returns-receivables relation motivate us to investigate why more financing is not provided to customers. We attempt to address this question by examining the value of receivables after conditioning on product market variables and financial constraints, both of which explain cross-sectional variation in the level of supplier financing.

Tables III-V report the influence of product market dynamics on the value of receivables. For these results, we interact $\triangle T R$ with the product market characteristics. For each interaction, we estimate three variants of Equation (1): a baseline model and separate estimations for concentrated and competitive industry subsamples.

22. For example, our sample consists of publicly traded firms. Such firms may extend trade credit to both public and private companies.

23. In earlier versions of this paper, we studied other issues related to the value of receivables. For example, we examined whether investments in receivables exhibit diminishing returns, as motivated by Scherr (1996), who discusses the importance of determining credit policy limits that maximize shareholder wealth; bad debt expenses may vary directly with the number of buyers receiving trade credit. We test for diminishing returns by interacting the change in receivables with the prior period level of receivables $\left(\Delta T R_{t}{ }^{*} T R_{t-1}\right)$. Results suggest diminishing returns to extending trade credit as $\Delta T R_{t}{ }^{*} T R_{t-1}$ is negatively signed, indicating current period increases in receivables are less valuable for firms with greater prior period receivables. In separate results, we include nonlinear terms $\left(\Delta T R^{2}\right.$ and $\left.\Delta T R^{3}\right) . \Delta T R^{2}$ and $\Delta T R^{3}$ are significant and positively and negatively signed, respectively. The cubed term's negative coefficient suggests the existence of a ceiling for the net benefit provided by supplier financing. This evidence is consistent with Scherr's (1996) view that trade credit exhibits diminishing returns because of greater default risk and collection losses associated with lending to new, less creditworthy customers. The results highlight the importance of actively managing and monitoring trade credit policies. Because our focus is on the interaction between trade receivables and product market factors and financial constraints, we leave further issues concerning trade credit limits to future research. 


\section{Table III. Product Market Influences on the Value of Trade Receivables}

This table presents fixed effects regressions estimating the market value of receivables per Equation (1). The dependent variable is excess returns, where the Fama and French (1993) size and book-to-market portfolio matched return is used as the benchmark portfolio. $\Delta X_{t}$ represents the one-year change in $X\left(X_{t}-X_{t-1}\right)$. Variables other than $L$ and Sales $G$ are scaled by the lagged market value of equity. $C$ is cash and marketable securities. $T R$ is trade receivables. $E$ is earnings defined as earnings before extraordinary items. NA is net assets calculated as total assets minus cash and receivables. $R D$ is research and development expenditures. $l$ is interest expense. $D$ is common dividends. $L$ is the market leverage ratio. NF is net new financing. SalesG is the percentage change in sales. CV_Sales is the coefficient of variation for annual sales. MktShare is firm sales divided by aggregate industry sales in a given year. Concentrated (competitive) industries have Herfindahl index values exceeding (not exceeding) the sample median annual Herfindahl index. Herfindahl calculations use Fama and French (1997) industry classifications. F-test results indicate differences in the respective interaction term across the concentrated and competitive subsamples. Models include time dummy variables. Unreported standard errors are robust to heteroskedasticity and cluster at the firm level. $t$-statistics appear in parentheses. Intercepts are omitted because of space constraints.

\begin{tabular}{|c|c|c|c|c|c|c|}
\hline $\begin{array}{l}\text { Independent } \\
\text { Variables }\end{array}$ & (1) & (2) & (3) & (4) & (5) & (6) \\
\hline$\overline{\Delta C_{i, t}}$ & $\begin{array}{l}0.655^{\text {***}} \\
(21.894)\end{array}$ & $\begin{array}{c}0.729^{* * *} \\
(16.411)\end{array}$ & $\begin{array}{l}0.585^{* * *} \\
(13.275)\end{array}$ & $\begin{array}{l}0.627^{\text {*** }} \\
(24.367)\end{array}$ & $\begin{array}{c}0.663^{* * *} \\
(17.396)\end{array}$ & $\begin{array}{c}0.583^{* * * *} \\
(15.335)\end{array}$ \\
\hline$\Delta T R_{i, t}$ & $\begin{array}{l}0.464^{* * *} \\
(9.997)\end{array}$ & $\begin{array}{l}0.475^{\text {*** }} \\
(5.986)\end{array}$ & $\begin{array}{l}0.454^{* * *} \\
(7.519)\end{array}$ & $\begin{array}{l}0.526^{* * *} \\
(17.777)\end{array}$ & $\begin{array}{c}0.565^{* * *} \\
(11.634)\end{array}$ & $\begin{array}{l}0.510^{* * *} \\
(12.505)\end{array}$ \\
\hline$\Delta E_{i, t}$ & $\begin{array}{l}0.619^{* * *} \\
(29.429)\end{array}$ & $\begin{array}{l}0.587^{\text {*** }} \\
(19.320)\end{array}$ & $\begin{array}{l}0.651^{\text {*** }} \\
(20.529)\end{array}$ & $\begin{array}{l}0.649^{* * *} \\
(33.571)\end{array}$ & $\begin{array}{c}0.636^{* * *} \\
(22.834)\end{array}$ & $\begin{array}{l}0.655^{\text {*** }} \\
(22.688)\end{array}$ \\
\hline$\Delta N A_{i, t}$ & $\begin{array}{l}0.093^{* * *} \\
(7.160)\end{array}$ & $\begin{array}{l}0.128^{\star \star *} \\
(6.514)\end{array}$ & $\begin{array}{l}0.073^{* * *} \\
(3.721)\end{array}$ & $\begin{array}{l}0.075^{\star * \star} \\
(6.636)\end{array}$ & $\begin{array}{l}0.098^{* * *} \\
(5.759)\end{array}$ & $\begin{array}{l}0.063^{* * *} \\
(3.818)\end{array}$ \\
\hline$\Delta R D_{i, t}$ & $\begin{array}{c}0.371 \\
(1.601)\end{array}$ & $\begin{array}{c}0.116 \\
(0.360)\end{array}$ & $\begin{array}{l}0.526 \\
(1.548)\end{array}$ & $\begin{array}{l}0.526^{\star * *} \\
(2.679)\end{array}$ & $\begin{array}{c}0.320 \\
(1.198)\end{array}$ & $\begin{array}{r}0.504^{*} \\
(1.718)\end{array}$ \\
\hline$\Delta l_{i, t}$ & $\begin{array}{l}-1.954^{* * *} \\
(-13.195)\end{array}$ & $\begin{array}{l}-2.104^{* * *} \\
(-8.726)\end{array}$ & $\begin{array}{l}-1.719^{* * *} \\
(-8.338)\end{array}$ & $\begin{array}{l}-1.719^{* * *} \\
(-13.432)\end{array}$ & $\begin{array}{l}-1.936^{* * *} \\
(-9.119)\end{array}$ & $\begin{array}{l}-1.453^{* * *} \\
(-8.415)\end{array}$ \\
\hline$\Delta D_{i, t}$ & $\begin{array}{l}0.793^{* *} \\
(2.239)\end{array}$ & $\begin{array}{l}-0.130 \\
(-0.225)\end{array}$ & $\begin{array}{l}1.245^{* *} \\
(2.532)\end{array}$ & $\begin{array}{l}1.074^{* * *} \\
(3.527)\end{array}$ & $\begin{array}{c}0.556 \\
(1.117)\end{array}$ & $\begin{array}{l}1.258^{* * *} \\
(2.971)\end{array}$ \\
\hline$L_{i, t}$ & $\begin{array}{l}-1.094^{* * *} \\
(-50.345)\end{array}$ & $\begin{array}{l}-1.127^{* * *} \\
(-33.925)\end{array}$ & $\begin{array}{c}-1.125^{\star \star *} \\
(-33.862)\end{array}$ & $\begin{array}{l}-1.067^{* * *} \\
(-57.049)\end{array}$ & $\begin{array}{c}-1.093^{* * *} \\
(-38.652)\end{array}$ & $\begin{array}{l}-1.092^{* * *} \\
(-38.065)\end{array}$ \\
\hline$N F_{i, t}$ & $\begin{array}{l}0.094^{* * *} \\
(4.194)\end{array}$ & $\begin{array}{c}0.046 \\
(1.377)\end{array}$ & $\begin{array}{l}0.105^{\star * *} \\
(3.176)\end{array}$ & $\begin{array}{l}0.134^{* * *} \\
(7.141)\end{array}$ & $\begin{array}{l}0.106^{* * *} \\
(3.770)\end{array}$ & $\begin{array}{l}0.129^{\text {*** }} \\
(4.681)\end{array}$ \\
\hline Sales $G_{i, t}$ & $\begin{array}{l}0.137^{* \star *} \\
(11.275)\end{array}$ & $\begin{array}{l}0.144^{\star * \star} \\
(7.931)\end{array}$ & $\begin{array}{l}0.118^{* \star \star} \\
(6.538)\end{array}$ & $\begin{array}{l}0.089^{* * *} \\
(10.038)\end{array}$ & $\begin{array}{l}0.096^{\star * *} \\
(7.294)\end{array}$ & $\begin{array}{l}0.088^{* * *} \\
(6.781)\end{array}$ \\
\hline$\Delta T R_{i, t}{ }^{*} C V \_$Sales $s_{i, t}$ & $\begin{array}{c}0.308^{\star} \\
(1.739) \\
-0.202^{\star * \star}\end{array}$ & $\begin{array}{c}0.492 \\
(1.628) \\
-0.159^{* \star *}\end{array}$ & $\begin{array}{c}0.143 \\
(0.606) \\
-0.237^{* * *}\end{array}$ & $\begin{array}{l}- \\
- \\
-\end{array}$ & $\begin{array}{l}- \\
- \\
-\end{array}$ & $\begin{array}{l}- \\
- \\
-\end{array}$ \\
\hline CV_Sales & $(-10.099)$ & $(-5.187)$ & $(-7.489)$ & - & - & - \\
\hline$\Delta T \bar{R}_{i, t}{ }^{*} M k t$ Share ${ }_{i, t}$ & $\begin{array}{l}- \\
-\end{array}$ & $\begin{array}{l}- \\
-\end{array}$ & $\begin{array}{l}- \\
-\end{array}$ & $\begin{array}{l}-1.993^{* * *} \\
(-3.374)\end{array}$ & $\begin{array}{l}-1.655^{\star * *} \\
-2.885)\end{array}$ & $\begin{array}{l}-6.346^{* * *} \\
(-3.872)\end{array}$ \\
\hline MktShare $_{i, t}$ & - & - & $\begin{array}{l}- \\
-\end{array}$ & $\begin{array}{l}-0.017 \\
(-0.177)\end{array}$ & $\begin{array}{l}-0.019 \\
(-0.175)\end{array}$ & $\begin{array}{l}-0.363 \\
(-1.279)\end{array}$ \\
\hline $\begin{array}{l}F \text {-test for difference } \\
\text { in interaction } \\
(p \text {-value })\end{array}$ & - & $\begin{array}{l}- \\
-\end{array}$ & $\begin{array}{l}2.170 \\
(0.141)\end{array}$ & $\begin{array}{l}- \\
-\end{array}$ & $-(0.004)$ & $8.190^{* * *}$ \\
\hline Fixed effects & $\begin{array}{r}\text { Firm and } \\
\text { time }\end{array}$ & $\begin{array}{r}\text { Firm and } \\
\text { time }\end{array}$ & $\begin{array}{r}\text { Firm and } \\
\text { time }\end{array}$ & $\begin{array}{r}\text { Firm and } \\
\text { time }\end{array}$ & $\begin{array}{r}\text { Firm and } \\
\text { time }\end{array}$ & $\begin{array}{r}\text { Firm and } \\
\text { time }\end{array}$ \\
\hline Sample & Full & Concentrated & Competitive & Full & Concentrated & Competitive \\
\hline Observations & 59,627 & 28,538 & 31,089 & 75,800 & 36,533 & 39,267 \\
\hline$R^{2}$ & 0.212 & 0.227 & 0.208 & 0.201 & 0.213 & 0.197 \\
\hline
\end{tabular}

*** Significant at the 0.01 level.

** Significant at the 0.05 level.

* Significant at the 0.10 level. 


\section{Table IV. Product Market Influences on the Value of Trade Receivables}

This table presents fixed effects regressions estimating the market value of receivables per Equation (1). The dependent variable is excess returns, where the Fama and French (1993) size and book-to-market portfolio matched return is used as the benchmark portfolio. $\Delta X_{t}$ represents the one-year change in $X\left(X_{t}-X_{t-1}\right)$. Variables other than $L$ and Sales $G$ are scaled by the lagged market value of equity. $C$ is cash and marketable securities. TR is trade receivables. $E$ is earnings defined as earnings before extraordinary items. NA is net assets calculated as total assets minus cash and receivables. $R D$ is research and development expenditures. $/$ is interest expense. $D$ is common dividends. $L$ is the market leverage ratio. NF is net new financing. SalesG is the percentage change in sales. DiffProd is an indicator variable equal to one if the firm produces differentiated products, and zero otherwise. Services is an indicator variable equal to one if the firm is a service provider, and zero otherwise. Firms not classified as DiffProd or Services are classified as producing standardized products representing the base case. SIC classifications used to identify DiffProd, StandardProd, and Services follow Giannetti et al. (2008). Concentrated (competitive) industries have Herfindahl index values exceeding (not exceeding) the sample median annual Herfindahl index. Herfindahl calculations use Fama and French (1997) industry classifications. F-test results indicate differences in the respective interaction term across the concentrated and competitive subsamples. Models include time dummy variables. Unreported standard errors are robust to heteroskedasticity and cluster at the firm level. $t$-statistics appear in parentheses. Intercepts are omitted because of space constraints.

\begin{tabular}{|c|c|c|c|}
\hline Independent Variables & (1) & (2) & (3) \\
\hline$\Delta C_{i, t}$ & $\begin{array}{l}0.625^{\star \star *} \\
(24.296)\end{array}$ & $\begin{array}{l}0.659^{* * *} \\
(17.263)\end{array}$ & $\begin{array}{l}0.584^{* * *} \\
(15.349)\end{array}$ \\
\hline$\Delta T R_{i, t}$ & $\begin{array}{l}0.457^{* * *} \\
(9.307)\end{array}$ & $\begin{array}{l}0.460^{* * *} \\
(5.013)\end{array}$ & $\begin{array}{l}0.446^{* * *} \\
(7.970)\end{array}$ \\
\hline$\Delta E_{i, t}$ & $\begin{array}{l}0.649^{* * *} \\
(33.602)\end{array}$ & $\begin{array}{l}0.637^{\star * *} \\
(22.894)\end{array}$ & $\begin{array}{l}0.652^{\star \star \star} \\
(22.633)\end{array}$ \\
\hline$\Delta N A_{i, t}$ & $\begin{array}{l}0.074^{* * *} \\
(6.574)\end{array}$ & $\begin{array}{l}0.098^{* * *} \\
(5.705)\end{array}$ & $\begin{array}{l}0.062^{* * *} \\
(3.758)\end{array}$ \\
\hline$\Delta R D_{i, t}$ & $\begin{array}{l}0.497^{* *} \\
(2.533)\end{array}$ & $\begin{array}{c}0.299 \\
(1.123)\end{array}$ & $\begin{array}{c}0.456 \\
(1.554)\end{array}$ \\
\hline$\Delta l_{i, t}$ & $\begin{array}{l}-1.726^{* * *} \\
(-13.466)\end{array}$ & $\begin{array}{l}-1.942^{* \star *} \\
(-9.134)\end{array}$ & $\begin{array}{l}-1.459^{* * *} \\
(-8.433)\end{array}$ \\
\hline$\Delta D_{i, t}$ & $\begin{array}{l}1.028^{* * *} \\
(3.374)\end{array}$ & $\begin{array}{c}0.485 \\
(0.972)\end{array}$ & $\begin{array}{l}1.222^{* * *} \\
(2.891)\end{array}$ \\
\hline$L_{i, t}$ & $\begin{array}{l}-1.068^{\star \star *} \\
(-57.066)\end{array}$ & $\begin{array}{l}-1.095^{\star \star *} \\
(-38.719)\end{array}$ & $\begin{array}{l}-1.093^{* * *} \\
(-38.051)\end{array}$ \\
\hline$N F_{i, t}$ & $\begin{array}{l}0.134^{* * *} \\
(7.148)\end{array}$ & $\begin{array}{l}0.107^{\star * *} \\
(3.789)\end{array}$ & $\begin{array}{l}0.129^{* * *} \\
(4.686)\end{array}$ \\
\hline Sales $G_{i, t}$ & $\begin{array}{l}0.089^{* * *} \\
(10.098)\end{array}$ & $\begin{array}{l}0.097^{* * *} \\
(7.394)\end{array}$ & $\begin{array}{l}0.088^{* * *} \\
(6.742)\end{array}$ \\
\hline$\Delta T R_{i, t}^{*} \operatorname{DiffProd}_{i, t}$ & $\begin{array}{r}0.103^{*} \\
(1.651)\end{array}$ & $\begin{array}{c}0.088 \\
(0.852)\end{array}$ & $\begin{array}{r}0.145^{*} \\
(1.666)\end{array}$ \\
\hline$\Delta T R_{i, t}{ }^{*}$ Services $_{i, t}$ & $\begin{array}{c}0.017 \\
(0.260)\end{array}$ & $\begin{array}{c}0.131 \\
(1.078)\end{array}$ & $\begin{array}{l}-0.080 \\
(-1.008)\end{array}$ \\
\hline $\begin{array}{l}F \text {-test for difference in } \\
\quad \Delta T R_{i, t}{ }^{*} \operatorname{DiffProd}_{i, t}(p \text {-value })\end{array}$ & - & - & $\begin{array}{c}0.430 \\
(0.512)\end{array}$ \\
\hline $\begin{array}{l}F \text {-test for difference in } \\
\Delta T R_{j, t}{ }^{*} \text { Services } \\
\text { ( }\end{array}$ & $\begin{array}{l}- \\
-\end{array}$ & - & $\begin{array}{l}7.070^{* * *} \\
(0.008)\end{array}$ \\
\hline Fixed effects & Firm and time & Firm and time & Firm and time \\
\hline Sample & Full & Concentrated & Competitive \\
\hline Observations & 75,800 & 36,533 & 39,267 \\
\hline$R^{2}$ & 0.200 & 0.213 & 0.197 \\
\hline
\end{tabular}

*** Significant at the 0.01 level.

** Significant at the 0.05 level.

* Significant at the 0.10 level. 


\section{Table V. Product Market Influences on the Value of Trade Receivables}

This table presents fixed effects regressions estimating the market value of receivables per Equation (1). The dependent variable is excess returns, where the Fama and French (1993) size and book-to-market portfolio matched return is used as the benchmark portfolio. $\Delta X_{t}$ represents the one-year change in $X\left(X_{t}-X_{t-1}\right)$. Variables other than $L$ and Sales $G$ are scaled by the lagged market value of equity. $C$ is cash and marketable securities. $T R$ is trade receivables. $E$ is earnings defined as earnings before extraordinary items. NA is net assets calculated as total assets minus cash and receivables. $R D$ is research and development expenditures. $l$ is interest expense. $D$ is common dividends. $L$ is the market leverage ratio. NF is net new financing. Sales $G$ is the percentage change in sales. Turn is asset turnover defined as sales divided by total assets minus receivables. Concentrated (competitive) industries have Herfindahl index values exceeding (not exceeding) the sample median annual Herfindahl index. Herfindahl calculations use Fama and French (1997) industry classifications. F-test results indicate differences in the respective interaction term across the concentrated and competitive subsamples. Models include time dummy variables. Unreported standard errors are robust to heteroskedasticity and cluster at the firm level. $t$-statistics appear in parentheses. Intercepts are omitted because of space constraints.

\begin{tabular}{|c|c|c|c|c|c|c|}
\hline $\begin{array}{l}\text { Independent } \\
\text { Variables }\end{array}$ & (1) & $(2)$ & (3) & (4) & (5) & $(6)$ \\
\hline$\Delta C_{i, t}$ & $\begin{array}{c}0.624^{\star * *} \\
(24.237)\end{array}$ & $\begin{array}{c}0.657^{\text {***}} \\
(17.217)\end{array}$ & $\begin{array}{c}0.583^{\star * *} \\
(15.316)\end{array}$ & $\begin{array}{c}0.633^{* * *} \\
(24.497)\end{array}$ & $\begin{array}{l}0.670^{* \star *} \\
(17.470)\end{array}$ & $\begin{array}{c}0.590^{* \star *} \\
(15.465)\end{array}$ \\
\hline$\Delta T R_{i, t}$ & $\begin{array}{l}0.504^{* * *} \\
(17.668)\end{array}$ & $\begin{array}{c}0.532^{* * *} \\
(11.450)\end{array}$ & $\begin{array}{l}0.480^{* * *} \\
(12.527)\end{array}$ & $\begin{array}{c}0.491^{* * *} \\
(12.300)\end{array}$ & $\begin{array}{l}0.462^{\star \star \star} \\
(7.606)\end{array}$ & $\begin{array}{l}0.499^{* * *} \\
(8.784)\end{array}$ \\
\hline$\Delta E_{i, t}$ & $\begin{array}{l}0.649^{* * *} \\
(33.549)\end{array}$ & $\begin{array}{l}0.636^{* * *} \\
(22.809)\end{array}$ & $\begin{array}{c}0.654^{* * *} \\
(22.650)\end{array}$ & $\begin{array}{c}0.645^{\star * *} \\
(33.401)\end{array}$ & $\begin{array}{l}0.633^{* \star *} \\
(22.699)\end{array}$ & $\begin{array}{l}0.650^{* * *} \\
(22.576)\end{array}$ \\
\hline$\Delta N A_{i, t}$ & $\begin{array}{l}0.074^{* * *} \\
(6.553)\end{array}$ & $\begin{array}{l}0.098^{* * *} \\
(5.734)\end{array}$ & $\begin{array}{l}0.060^{\star * *} \\
(3.661)\end{array}$ & $\begin{array}{l}0.083^{* * *} \\
(7.273)\end{array}$ & $\begin{array}{l}0.111^{* * *} \\
(6.307)\end{array}$ & $\begin{array}{l}0.067^{\text {*** }} \\
(4.103)\end{array}$ \\
\hline$\Delta R D_{i, t}$ & $\begin{array}{l}0.503^{* *} \\
(2.570)\end{array}$ & $\begin{array}{c}0.290 \\
(1.090)\end{array}$ & $\begin{array}{c}0.477 \\
(1.639)\end{array}$ & $\begin{array}{l}0.508^{* * *} \\
(2.597)\end{array}$ & $\begin{array}{c}0.303 \\
(1.140)\end{array}$ & $\begin{array}{r}0.483^{*} \\
(1.650)\end{array}$ \\
\hline$\Delta l_{i, t}$ & $\begin{array}{l}-1.720^{\text {*** }} \\
(-13.428)\end{array}$ & $\begin{array}{l}-1.948^{* * *} \\
(-9.169)\end{array}$ & $\begin{array}{l}-1.446^{\star * *} \\
(-8.365)\end{array}$ & $\begin{array}{l}-1.717^{\star \star *} \\
(-13.414)\end{array}$ & $\begin{array}{l}-1.930^{* \star *} \\
(-9.107)\end{array}$ & $\begin{array}{l}-1.450^{* * *} \\
(-8.382)\end{array}$ \\
\hline$\Delta D_{i, t}$ & $\begin{array}{l}1.007^{* * *} \\
(3.305)\end{array}$ & $\begin{array}{c}0.447 \\
(0.897)\end{array}$ & $\begin{array}{l}1.196^{\star * *} \\
(2.823)\end{array}$ & $\begin{array}{l}0.970^{* * *} \\
(3.183)\end{array}$ & $\begin{array}{c}0.379 \\
(0.763)\end{array}$ & $\begin{array}{l}1.183^{* * *} \\
(2.793)\end{array}$ \\
\hline$L_{i, t}$ & $\begin{array}{l}-1.071^{\text {*** }} \\
(-57.178)\end{array}$ & $\begin{array}{l}-1.098^{\star * *} \\
(-38.844)\end{array}$ & $\begin{array}{l}-1.096^{\star \star *} \\
(-38.130)\end{array}$ & $\begin{array}{l}-1.053^{* * *} \\
(-55.950)\end{array}$ & $\begin{array}{l}-1.077^{\star * *} \\
(-37.685)\end{array}$ & $\begin{array}{l}-1.079^{\text {*** }} \\
(-37.495)\end{array}$ \\
\hline$N F_{i, t}$ & $\begin{array}{l}0.133^{* * *} \\
(7.042)\end{array}$ & $\begin{array}{l}0.105^{* * *} \\
(3.706)\end{array}$ & $\begin{array}{l}0.127^{* * *} \\
(4.627)\end{array}$ & $\begin{array}{l}0.140^{* * *} \\
(7.408)\end{array}$ & $\begin{array}{l}0.114^{* * *} \\
(4.038)\end{array}$ & $\begin{array}{l}0.133^{* * *} \\
(4.810)\end{array}$ \\
\hline Sales $G_{i, t}$ & $\begin{array}{l}0.088^{* \star *} \\
(9.967)\end{array}$ & $\begin{array}{l}0.096^{* * *} \\
(7.293)\end{array}$ & $\begin{array}{l}0.087^{* * *} \\
(6.710)\end{array}$ & $\begin{array}{l}0.086^{* * *} \\
(9.668)\end{array}$ & $\begin{array}{l}0.092^{* * *} \\
(7.013)\end{array}$ & $\begin{array}{l}0.085^{* \star *} \\
(6.515)\end{array}$ \\
\hline$\Delta T R_{i, t}{ }^{*} \Delta R D_{i, t}$ & $\begin{array}{l}5.749^{* * *} \\
(4.044)\end{array}$ & $\begin{array}{l}6.084^{* * *} \\
(3.163)\end{array}$ & $\begin{array}{l}5.913^{\star *} \\
(2.529)\end{array}$ & - & - & - \\
\hline$\Delta T R_{i, t}{ }^{*} \operatorname{Turn}_{i, t}$ & - & - & $\begin{array}{l}- \\
-\end{array}$ & $\begin{array}{c}0.001 \\
(0.063)\end{array}$ & $\begin{array}{c}0.023 \\
(1.445)\end{array}$ & $\begin{array}{l}-0.011 \\
(-0.810)\end{array}$ \\
\hline Turn $_{i, t}$ & - & - & - & $\begin{array}{l}0.026^{* * *} \\
(4.841)\end{array}$ & $\begin{array}{l}0.035^{* * *} \\
(3.631)\end{array}$ & $\begin{array}{l}0.021^{* * *} \\
(3.717)\end{array}$ \\
\hline $\begin{array}{l}F \text {-test for } \\
\text { difference in } \\
\text { interaction } \\
(p \text {-value })\end{array}$ & $\begin{array}{l}- \\
-\end{array}$ & - & $\begin{array}{c}0.010 \\
(0.942)\end{array}$ & $\begin{array}{l}- \\
-\end{array}$ & $\begin{array}{l}- \\
-\end{array}$ & $\begin{array}{l}6.160^{* *} \\
(0.013)\end{array}$ \\
\hline Fixed effects & $\begin{array}{r}\text { Firm and } \\
\text { time }\end{array}$ & $\begin{array}{r}\text { Firm and } \\
\text { time }\end{array}$ & $\begin{array}{r}\text { Firm and } \\
\text { time }\end{array}$ & $\begin{array}{r}\text { Firm and } \\
\text { time }\end{array}$ & $\begin{array}{r}\text { Firm and } \\
\text { time }\end{array}$ & $\begin{array}{r}\text { Firm and } \\
\text { time }\end{array}$ \\
\hline Sample & Full & Concentrated & Competitive & Full & Concentrated & Competitive \\
\hline Observations & 75,800 & 36,533 & 39,267 & 75,800 & 36,533 & 39,267 \\
\hline$R^{2}$ & 0.201 & 0.213 & 0.198 & 0.201 & 0.214 & 0.198 \\
\hline
\end{tabular}

*** Significant at the 0.01 level.

** Significant at the 0.05 level.

* Significant at the 0.10 level. 
The first product market characteristic we examine is demand uncertainty (CV_Sales). Supporting earlier results, the correlation between excess returns and receivables remains positive and significant. Evidence also suggests a negative relationship between equity returns and demand uncertainty. We find a direct and marginally significant association between shareholder wealth and $\triangle T R^{*} C V \_$Sales. Correlation between the fixed firm effects and $C V \_$Sales may explain the interaction's weak statistical significance. Even though $C V \_$Sales is a rolling measure, it is fairly static by construction, thereby providing an additional pseudo-fixed effect. When reestimating the model using OLS, we find that the interaction increases in statistical significance $(p$-value $=0.041)$ and that the coefficient estimate $(0.300)$ changes only marginally. This supports our conjecture that the correlation between the firm effects and CV_Sales reduces the significance level for the interaction.

The results of column 1 in Table III indicate that the value of an additional dollar in receivables for a firm with no variation in sales is $\$ 0.46$, but increases to $\$ 0.53[\$ 0.46+(\$ 0.31 \times 0.23)]$ for firms with average demand uncertainty. ${ }^{24}$ The statistical significance of the interaction disappears once we split the sample according to industry structure.

The positive receivables-sales volatility interaction is consistent with the market recognizing the strategic importance of trade credit in mitigating the costs of sales fluctuations. This supports Emery's (1987) model by demonstrating that trade credit policy reduces costs for suppliers who can finance trade credit cheaper than inventory. This is an important finding because of the mixed evidence with respect to sales variability as a determinant of trade credit levels. Long et al. (1993) report that receivables vary directly with sales volatility, although Deloof and Jegers (1996) and $\mathrm{Ng}$ et al. (1999) find evidence that is inconsistent with the operating motive. Although our results do not address whether demand uncertainty influences the extension of trade credit, they do suggest shareholders value an increase in trade credit more for firms facing greater demand uncertainty. Overall, the results are consistent with Emery's (1987) operating motive and H2.

Next, we examine whether the product quality motive influences the value of trade receivables. Table III (columns 4-6) displays our results after conditioning receivables on market share. The findings indicate excess returns are insignificantly related to MktShare. This insignificant relation is likely because of our use of excess returns as the dependent variable. Because larger firms typically have greater market shares, the return component driven by market share is accounted for via the benchmark return.

The variable of interest $\left(\Delta T R^{*} M k t\right.$ Share $)$ is negative and significant at the $1 \%$ level for the full sample. This finding has a couple of interpretations. First, the direct receivables market power result is consistent with the weakened benefit of the product quality signal associated with trade credit extension for firms with increased reputational capital (Long et al., 1993). In addition, this interaction suggests the market recognizes that firms with greater market share have less incentive to extend trade credit to stimulate sales growth (Nadiri, 1969; Schwartz, 1974). For both rationales, the equity market discounts the value of receivables for suppliers with greater market power. The coefficient estimates for $\Delta T R^{*} M k t S h a r e$ are significantly different across the industry concentration subsamples. In fact, the interaction is almost four times greater for the competitive subsample.

We re-estimate results (untabulated) using alternative proxies for market power. First, we replace MktShare with a dummy variable indicating whether a firm's market share exceeds the annual industry median. Using this approach, results indicate that the value of an incremental \$1 in receivables is reduced by $\$ 0.20$ for firms with strong market share. In addition, we measure market power as firm size, defined as the natural logarithm of net assets. Evidence confirms the value of trade receivables decreases with firm size, consistent with the view that the benefit of extending trade credit decreases with suppliers' reputation.

24. Summary statistics appear in Table I. 
In Table IV, we include interactions between $\Delta T R$ and dummy variables indicating whether the firm produces differentiated or standardized products (base case) or is a service provider. Column 1 results suggest insignificant differences in the market value of receivables for service firms and producers of standardized goods. Our findings indicate the market value of trade receivables is greater (\$0.10 premium) for firms selling differentiated products, relative to those selling standardized goods. This interaction is significant at the $10 \%$ level, but in untabulated results, the interaction strengthens in significance $(p$-value $=0.036)$ after dropping the firm effects and estimating with OLS. The market value premium for extending trade credit for firms producing differentiated products exists only for firms in competitive industries.

The baseline result provides some support for Long et al.'s (1993) theoretical model showing that trade credit is most beneficial for firms producing goods that are less commoditized as it takes buyers more time to assess the quality of differentiated products. In addition to the product quality motive, the positively signed interaction $\Delta T R^{*}$ DiffProd is consistent with firms producing differentiated products having less risk in extending supplier financing because of less competition, implying high switching costs (Giannetti et al., 2008) and/or a better ability to assess liquidation values of repossessed goods relative to financial institutions (Burkart and Ellingsen, 2004).

In untabulated results, we interact $\triangle T R$ with industry dummies based on alternative industry definitions. Specifically, we follow Long et al. (1993) and separate firms into those producing technical goods $(3,400 \leq \mathrm{SIC} \leq 3,900)$, perishable items $(2,000 \leq \mathrm{SIC} \leq 2,199)$, and all remaining industries. The results suggest that relative to the base case, the value of receivables increases (decreases) significantly for firms selling technical (perishable) products. Consistent with earlier industry interactions, these findings support the product quality motive.

Baseline results in Table $\mathrm{V}$ indicate that excess returns are positively associated with $\triangle R D$ and that the value of receivables increases with R\&D expenses. The interaction $\triangle T R^{*} R D$ is positive and statistically significant for each set of results. These findings support the view that the importance of assessing product quality influences the benefits of trade credit policy. Firms with greater R\&D expenses are likely to produce more technical goods. Although Deloof and Jegers (1996) do not find that $R \& D$ expenses influence trade credit levels, we report a market value premium for receivables held by firms with higher R\&D spending.

As a final test of the value premium associated with extending trade credit to mitigate product quality concerns, we interact receivables with asset turnover (sales divided by net assets), which proxies production cycle time. Shareholder wealth is directly and significantly related to asset turnover, but we find no evidence that the value of receivables varies with the length of the production cycle.

On balance, the evidence supports H3 suggesting that the market recognizes trade credit as a channel to manage product market frictions. Equity market participants recognize the impact of product quality assurance on the value of receivables through firm reputation, industry affiliation, and investments in R\&D.

\section{Financial Constraint}

Next, we examine the impact of financial constraint on the market value of trade receivables. Results for both $U C 2 \_D V$ and $U C 3 \_D V$ indicate constrained firms earn a risk premium relative to unconstrained firms. The results in columns 1 and 4 of Table VI suggest equity holders discount supplier financing provided by financially unconstrained firms. The interaction terms $\triangle T R^{*} U C 2 \_D V$ and $\triangle T R^{*} U C 3 \_D V$ are negatively signed and statistically significant at the $1 \%$ level, and the coefficient estimates provide meaningful economic interpretations. For example, the results in column 1 


\section{Table VI. Financial Constraint and the Value of Trade Receivables}

This table presents fixed effects regressions estimating the market value of receivables per Equation (1). The dependent variable is excess returns, where the Fama and French (1993) size and book-to-market portfolio matched return is used as the benchmark portfolio. $\Delta X_{t}$ represents the one-year change in $X\left(X_{t}-X_{t-1}\right)$. Variables other than $L$ and Sales $G$ are scaled by the lagged market value of equity. $C$ is cash and marketable securities. TR is trade receivables. $E$ is earnings defined as earnings before extraordinary items. $N A$ is net assets calculated as total assets minus cash and receivables. $R D$ is research and development expenditures. I is interest expense. $D$ is common dividends. $L$ is the market leverage ratio. $N F$ is net new financing. Sales $G$ is the percentage change in sales. UC2_DV is an indicator variable equal to one if the observation is deemed financially constrained by at least two financial constraint criteria, and zero otherwise. UC3_DV is an indicator variable equal to one if the observation is deemed financially constrained by at least three financial constraint criteria, and zero otherwise. Concentrated (competitive) industries have Herfindahl index values exceeding (not exceeding) the sample median annual Herfindahl index. Herfindahl calculations use Fama and French (1997) industry classifications. F-test results indicate differences in the respective interaction term across the concentrated and competitive subsamples. Models include time-dummy variables. Unreported standard errors are robust to heteroskedasticity and cluster at the firm level. $t$-statistics appear in parentheses. Intercepts are omitted because of space constraints.

\begin{tabular}{|c|c|c|c|c|c|c|}
\hline $\begin{array}{l}\text { Independent } \\
\text { Variables }\end{array}$ & (1) & (2) & (3) & (4) & (5) & (6) \\
\hline$\Delta C_{i, t}$ & $\begin{array}{l}0.625^{\star * *} \\
(24.311)\end{array}$ & $\begin{array}{c}0.661^{* * *} \\
(17.352)\end{array}$ & $\begin{array}{c}0.583^{* * *} \\
(15.317)\end{array}$ & $\begin{array}{l}0.625^{\star * *} \\
(24.298)\end{array}$ & $\begin{array}{c}0.660^{* \star *} \\
(17.300)\end{array}$ & $\begin{array}{c}0.584^{\star * *} \\
(15.331)\end{array}$ \\
\hline \multirow[t]{2}{*}{$\begin{array}{l}\Delta T R_{i, t} \\
0.489^{\star \star *}\end{array}$} & $0.547^{* \star \star}$ & $0.594^{* * *}$ & $0.509^{* * *}$ & $0.520^{\star * \star *}$ & $0.557^{* * *}$ & \\
\hline & (17.590) & (11.603) & (12.347) & (17.699) & (11.552) & (12.495) \\
\hline$\Delta E_{i, t}$ & $\begin{array}{l}0.647^{* * *} \\
(33.462)\end{array}$ & $\begin{array}{c}0.635^{\star * *} \\
(22.784)\end{array}$ & $\begin{array}{c}0.652^{* * *} \\
(22.556)\end{array}$ & $\begin{array}{c}0.649^{* * *} \\
(33.565)\end{array}$ & $\begin{array}{c}0.636^{* * *} \\
(22.816)\end{array}$ & $\begin{array}{l}0.655^{\star * *} \\
(22.679)\end{array}$ \\
\hline$\Delta N A_{i, t}$ & $\begin{array}{l}0.077^{* * *} \\
(6.813)\end{array}$ & $\begin{array}{l}0.101^{* * *} \\
(5.861)\end{array}$ & $\begin{array}{l}0.063^{\star * *} \\
(3.869)\end{array}$ & $\begin{array}{l}0.075^{\star * *} \\
(6.652)\end{array}$ & $\begin{array}{l}0.099^{* * *} \\
(5.767)\end{array}$ & $\begin{array}{l}0.062^{* * *} \\
(3.779)\end{array}$ \\
\hline$\Delta R D_{i, t}$ & $\begin{array}{l}0.520^{* * *} \\
(2.652)\end{array}$ & $\begin{array}{c}0.309 \\
(1.159)\end{array}$ & $\begin{array}{r}0.499^{*} \\
(1.702)\end{array}$ & $\begin{array}{l}0.521^{* * *} \\
(2.655)\end{array}$ & $\begin{array}{c}0.313 \\
(1.173)\end{array}$ & $\begin{array}{r}0.497^{*} \\
(1.694)\end{array}$ \\
\hline$\Delta l_{i, t}$ & $\begin{array}{l}-1.710^{\star * *} \\
(-13.339)\end{array}$ & $\begin{array}{l}-1.920^{* * *} \\
(-9.034)\end{array}$ & $\begin{array}{l}-1.450^{* * *} \\
(-8.374)\end{array}$ & $\begin{array}{l}-1.718^{\star \star *} \\
(-13.417)\end{array}$ & $\begin{array}{l}-1.932^{* * *} \\
(-9.087)\end{array}$ & $\begin{array}{l}-1.458^{\star * *} \\
(-8.432)\end{array}$ \\
\hline$\Delta D_{i, t}$ & $\begin{array}{l}1.117^{* * *} \\
(3.668)\end{array}$ & $\begin{array}{c}0.638 \\
(1.281)\end{array}$ & $\begin{array}{l}1.264^{* * *} \\
(2.984)\end{array}$ & $\begin{array}{l}1.075^{* * *} \\
(3.533)\end{array}$ & $\begin{array}{c}0.552 \\
(1.108)\end{array}$ & $\begin{array}{l}1.247^{\star * \star} \\
(2.948)\end{array}$ \\
\hline$L_{i, t}$ & $\begin{array}{l}-1.063^{* \star *} \\
(-56.874)\end{array}$ & $\begin{array}{l}-1.091^{* * *} \\
(-38.605)\end{array}$ & $\begin{array}{l}-1.088^{* * *} \\
(-37.945)\end{array}$ & $\begin{array}{l}-1.067^{* * *} \\
(-57.007)\end{array}$ & $\begin{array}{l}-1.094^{* * *} \\
(-38.645)\end{array}$ & $\begin{array}{l}-1.092^{* * *} \\
(-38.023)\end{array}$ \\
\hline$N F_{i, t}$ & $\begin{array}{l}0.135^{\star * *} \\
(7.170)\end{array}$ & $\begin{array}{l}0.108^{\star * *} \\
(3.822)\end{array}$ & $\begin{array}{l}0.129^{\star * *} \\
(4.697)\end{array}$ & $\begin{array}{l}0.134^{* \star *} \\
(7.122)\end{array}$ & $\begin{array}{l}0.106^{\star * *} \\
(3.757)\end{array}$ & $\begin{array}{l}0.129^{* \star *} \\
(4.686)\end{array}$ \\
\hline SalesG $_{i, t}$ & $\begin{array}{c}0.089^{* * *} \\
(10.044)\end{array}$ & $\begin{array}{l}0.096^{* * *} \\
(7.311)\end{array}$ & $\begin{array}{l}0.088^{* * *} \\
(6.763)\end{array}$ & $\begin{array}{l}0.089^{* * *} \\
(10.091)\end{array}$ & $\begin{array}{l}0.097^{\star * *} \\
(7.370)\end{array}$ & $\begin{array}{l}0.088^{\star * *} \\
(6.770)\end{array}$ \\
\hline$\Delta T R_{i, t}{ }^{*} U C 2 \_D V_{i, t}$ & $\begin{array}{l}-0.330^{* * *} \\
(-6.242)\end{array}$ & $\begin{array}{l}-0.400^{* * *} \\
(-4.726)\end{array}$ & $\begin{array}{l}-0.267^{* * *} \\
(-3.640)\end{array}$ & - & - & - \\
\hline$U C 2 \_D V_{i, t}$ & $\begin{array}{l}-0.048^{* * *} \\
(-6.264)\end{array}$ & $\begin{array}{l}-0.044^{* * *} \\
(-3.535)\end{array}$ & $\begin{array}{l}-0.052^{* * *} \\
(-4.705)\end{array}$ & - & - & - \\
\hline${ }_{-} T T R_{i, t}{ }^{*} U C 3 \_D V_{i, t}$ & $\begin{array}{l}- \\
-\end{array}$ & $\begin{array}{l}- \\
-\end{array}$ & $(-\overline{5.046)}$ & $\begin{array}{l}-0.363^{* * *} \\
(-3.514)\end{array}$ & $\begin{array}{l}-0.376^{* * *} \\
(-3.419)\end{array}$ & $-0.371^{\star \star \star}$ \\
\hline UC3_DV $V_{i, t}$ & $\begin{array}{l}- \\
-\end{array}$ & $\begin{array}{l}- \\
-\end{array}$ & $(-\overline{3.245)}$ & $\begin{array}{l}-0.027^{* * *} \\
(-2.632)\end{array}$ & $\begin{array}{l}-0.034^{* * *} \\
(-1.925)\end{array}$ & $-0.023^{*}$ \\
\hline $\begin{array}{l}F \text {-test for difference } \\
\text { in interaction } \\
\text { (p-value) }\end{array}$ & - & $\begin{array}{l}- \\
-\end{array}$ & $\begin{array}{l}3.320^{*} \\
(0.069)\end{array}$ & $\begin{array}{l}- \\
-\end{array}$ & $\begin{array}{l}- \\
-\end{array}$ & $\begin{array}{c}0.000 \\
(0.961)\end{array}$ \\
\hline Fixed effects Firm & $m$ and time & Firm and time & Firm and time & Firm and time & Firm and time & Firm and time \\
\hline Observations & 75,800 & 36,533 & 39,267 & 75,800 & 36,533 & 39,267 \\
\hline$R^{2}$ & 0.201 & 0.214 & 0.198 & 0.201 & 0.213 & 0.197 \\
\hline
\end{tabular}

*** Significant at the 0.01 level.

** Significant at the 0.05 level.

* Significant at the 0.10 level. 


\section{Table VII. Financial Constraint and the Value of Trade Receivables}

This table presents fixed effects regressions estimating the market value of receivables per Equation (1). The dependent variable is excess returns, where the Fama and French (1993) size and book-to-market portfolio matched return is used as the benchmark portfolio. $\Delta X_{t}$ represents the one-year change in $X\left(X_{t}-X_{t-1}\right)$. Variables other than $L$ and Sales $G$ are scaled by the lagged market value of equity. $C$ is cash and marketable securities. TR is trade receivables. $E$ is earnings defined as earnings before extraordinary items. NA is net assets calculated as total assets minus cash and receivables. $R D$ is research and development expenditures. $I$ is interest expense. $D$ is common dividends. $L$ is the market leverage ratio. NF is net new financing. SalesG is the percentage change in sales. Concentrated (competitive) industries have Herfindahl index values exceeding (not exceeding) the sample median annual Herfindahl index. Herfindahl calculations use Fama and French (1997) industry classifications. F-test results indicate differences in the respective interaction term across the concentrated and competitive subsamples. Models include time dummy variables. Unreported standard errors are robust to heteroskedasticity and cluster at the firm level. $t$-statistics appear in parentheses. Intercepts are omitted because of space constraints.

\begin{tabular}{|c|c|c|c|c|c|c|}
\hline $\begin{array}{l}\text { Independent } \\
\text { Variables }\end{array}$ & (1) & (2) & (3) & (4) & (5) & (6) \\
\hline$\Delta C_{i, t}$ & $\begin{array}{c}0.885^{\star * *} \\
(30.595)\end{array}$ & $\begin{array}{l}0.907^{\star * *} \\
(21.717)\end{array}$ & $\begin{array}{c}0.860^{* * *} \\
(19.559)\end{array}$ & $\begin{array}{c}0.641^{* * *} \\
(24.975)\end{array}$ & $\begin{array}{l}0.677^{\star * *} \\
(17.754)\end{array}$ & $\begin{array}{l}0.598^{* * *} \\
(15.800)\end{array}$ \\
\hline$\Delta T R_{i, t}$ & $\begin{array}{c}0.531^{\text {***}} \\
(14.249)\end{array}$ & $\begin{array}{l}0.553^{* * *} \\
(8.929)\end{array}$ & $\begin{array}{c}0.499^{* * *} \\
(10.463)\end{array}$ & $\begin{array}{c}1.346^{* * *} \\
(20.619)\end{array}$ & $\begin{array}{c}1.326^{* * *} \\
(13.146)\end{array}$ & $\begin{array}{c}1.349^{* * *} \\
(15.060)\end{array}$ \\
\hline$\Delta E_{i, t}$ & $\begin{array}{c}0.594^{* * *} \\
(30.998)\end{array}$ & $\begin{array}{c}0.587^{* \star *} \\
(21.372)\end{array}$ & $\begin{array}{c}0.594^{* * *} \\
(20.685)\end{array}$ & $\begin{array}{c}0.653^{\star * *} \\
(33.742)\end{array}$ & $\begin{array}{c}0.638^{* * *} \\
(22.887)\end{array}$ & $\begin{array}{c}0.661^{* * *} \\
(22.844)\end{array}$ \\
\hline$\Delta N A_{i, t}$ & $\begin{array}{l}0.072^{\star \star *} \\
(6.491)\end{array}$ & $\begin{array}{l}0.096^{* * *} \\
(5.641)\end{array}$ & $\begin{array}{l}0.059^{* \star *} \\
(3.690)\end{array}$ & $\begin{array}{l}0.082^{\star * *} \\
(7.249)\end{array}$ & $\begin{array}{l}0.104^{* * *} \\
(6.027)\end{array}$ & $\begin{array}{l}0.069^{* \star *} \\
(4.202)\end{array}$ \\
\hline$\Delta R D_{i, t}$ & $\begin{array}{l}0.620^{* * *} \\
(3.241)\end{array}$ & $\begin{array}{c}0.402 \\
(1.532)\end{array}$ & $\begin{array}{l}0.603^{* *} \\
(2.116)\end{array}$ & $\begin{array}{l}0.402^{* *} \\
(2.060)\end{array}$ & $\begin{array}{c}0.190 \\
(0.711)\end{array}$ & $\begin{array}{c}0.408 \\
(1.408)\end{array}$ \\
\hline$\Delta l_{i, t}$ & $\begin{array}{l}-1.427^{* * *} \\
(-11.270)\end{array}$ & $\begin{array}{l}-1.674^{* * *} \\
(-8.020)\end{array}$ & $\begin{array}{l}-1.119^{* * *} \\
(-6.577)\end{array}$ & $\begin{array}{l}-1.584^{* * *} \\
(-12.446)\end{array}$ & $\begin{array}{l}-1.773^{* * *} \\
(-8.386)\end{array}$ & $\begin{array}{l}-1.359^{* * *} \\
(-7.881)\end{array}$ \\
\hline$\Delta D_{i, t}$ & $\begin{array}{l}0.755^{* *} \\
(2.503)\end{array}$ & $\begin{array}{l}0.273 \\
(0.550)\end{array}$ & $\begin{array}{r}0.789^{*} \\
(1.900)\end{array}$ & $\begin{array}{l}0.998^{* * *} \\
(3.307)\end{array}$ & $\begin{array}{c}0.524 \\
(1.056)\end{array}$ & $\begin{array}{l}1.127^{* * *} \\
(2.684)\end{array}$ \\
\hline$L_{i, t}$ & $\begin{array}{l}-1.096^{\star * *} \\
(-56.049)\end{array}$ & $\begin{array}{l}-1.105^{\star * \star} \\
(-38.307)\end{array}$ & $\begin{array}{l}-1.144^{* * *} \\
(-37.919)\end{array}$ & $\begin{array}{l}-1.075^{\star \star *} \\
(-57.533)\end{array}$ & $\begin{array}{l}-1.104^{* * *} \\
(-38.924)\end{array}$ & $\begin{array}{l}-1.098^{* * *} \\
(-38.613)\end{array}$ \\
\hline$N F_{i, t}$ & $\begin{array}{l}0.137^{* * *} \\
(7.405)\end{array}$ & $\begin{array}{l}0.104^{* * *} \\
(3.752)\end{array}$ & $\begin{array}{l}0.139^{\star * *} \\
(5.188)\end{array}$ & $\begin{array}{l}0.137^{\star * *} \\
(7.365)\end{array}$ & $\begin{array}{l}0.108^{* * *} \\
(3.839)\end{array}$ & $\begin{array}{l}0.137^{\star * *} \\
(5.037)\end{array}$ \\
\hline Sales $G_{i, t}$ & $\begin{array}{l}0.092^{* * *} \\
(10.365)\end{array}$ & $\begin{array}{l}0.100^{* * *} \\
(7.549)\end{array}$ & $\begin{array}{l}0.091^{* * *} \\
(6.991)\end{array}$ & $\begin{array}{l}0.065^{* * *} \\
(7.370)\end{array}$ & $\begin{array}{l}0.073^{* * *} \\
(5.568)\end{array}$ & $\begin{array}{l}0.063^{* * *} \\
(4.899)\end{array}$ \\
\hline$\Delta T R_{i, t}{ }^{*} C_{i, t-1}$ & $\begin{array}{l}-0.159 \\
(-1.342)\end{array}$ & $\begin{array}{l}-0.080 \\
(-0.357)\end{array}$ & $\begin{array}{l}-0.171 \\
(-1.316)\end{array}$ & $\begin{array}{l}- \\
-\end{array}$ & $\begin{array}{l}- \\
-\end{array}$ & $\begin{array}{l}- \\
-\end{array}$ \\
\hline$C_{i, t-1}$ & $\begin{array}{c}0.685^{\star * *} \\
(23.537)\end{array}$ & $\begin{array}{c}0.673^{* * *} \\
(15.614)\end{array}$ & $\begin{array}{c}0.708^{* * *} \\
(16.229)\end{array}$ & - & - & - \\
\hline$\Delta T R_{i, t}{ }^{*} L_{i, t-1}$ & $\begin{array}{l}- \\
-\end{array}$ & $\begin{array}{l}- \\
-\end{array}$ & $\begin{array}{l}- \\
-\end{array}$ & $\begin{array}{c}-2.060^{* * *} \\
(-18.112)\end{array}$ & $\begin{array}{l}-1.986^{* * *} \\
(-11.234)\end{array}$ & $\begin{array}{l}-2.081^{* * *} \\
(-13.291)\end{array}$ \\
\hline $\begin{array}{l}F \text {-test for } \\
\text { difference in } \\
\text { interaction } \\
\text { ( } p \text {-value })\end{array}$ & $\begin{array}{l}- \\
-\end{array}$ & - & $\begin{array}{c}0.490 \\
(0.484)\end{array}$ & $\begin{array}{l}- \\
-\end{array}$ & $\begin{array}{l}- \\
-\end{array}$ & $\begin{array}{c}0.370 \\
(0.543)\end{array}$ \\
\hline $\begin{array}{l}\text { Fixed effects } \\
\text { Sample }\end{array}$ & $\begin{array}{r}\text { Firm and time } \\
\text { Full }\end{array}$ & $\begin{array}{l}\text { Firm and time } \\
\text { Concentrated }\end{array}$ & $\begin{array}{l}\text { Firm and time } \\
\text { Competitive }\end{array}$ & $\begin{array}{r}\text { Firm and time } \\
\text { Full }\end{array}$ & $\begin{array}{l}\text { Firm and time } \\
\text { Concentrated }\end{array}$ & $\begin{array}{r}\text { Firm and time } \\
\text { Competitive }\end{array}$ \\
\hline Observations & 75,800 & 36,533 & 39,267 & 75,800 & 36,533 & 39,267 \\
\hline$R^{2}$ & 0.228 & 0.238 & 0.228 & 0.210 & 0.222 & 0.207 \\
\hline
\end{tabular}

*** Significant at the 0.01 level.

** Significant at the 0.05 level.

* Significant at the 0.10 level. 
report that the market value of an additional dollar in receivables is worth $\$ 0.33$ less (more) if the firm is financially unconstrained (constrained). The interpretation of the coefficient on $\Delta T R^{*} U C 3_{-}$ $D V$ (column 4) is consistent with that in column 1, yet the estimate provides a stronger economic interpretation.

The negative financial constraint interactions are robust across the degree of industry competition. In unreported results, we re-estimate financial constraint models using the individual measures determining UC2_DV and UC3_DV (payout, size, bond, and commercial paper rating). Each interaction is negative and significant at the $1 \%$ level suggesting a discount ranging between $\$ 0.23$ (payout) and $\$ 0.47$ (size) for marginal receivables carried by constrained firms.

The evidence in Table VI strongly suggests lower values of receivables for unconstrained firms. These results are consistent with equity holders viewing receivables held by constrained firms as near cash. Unconstrained firms have stronger capital market access and cheaper financing. Subsequently, they have little to gain from additional liquidity, so investors discount their receivables. Although the extant literature indicates that trade credit extension is directly related to financial flexibility and the degree of financial unconstraint (Calomiris et al., 1995; Petersen and Rajan, 1997), our findings do not imply a premium in the market value of receivables for firms with cheaper external financing costs and an improved strategic ability to extend trade credit. Instead, our evidence suggests that the liquidity value of receivables is likely first-order among the competing explanations.

We also examine the impact of cash holdings on the change in trade receivables. The results in Table VII provide no evidence of lower valued receivables for firms with greater lagged cash holdings. Even though cash rich firms can more easily extend trade credit, our results do not indicate that cash holdings affect the value of receivables. Although untabulated, we re-estimate the results after splitting the sample into constrained and unconstrained firms and continue to find insignificant interaction between prior period cash and changes in receivables. This positive relation between excess returns and prior period cash holdings is consistent with Faulkender and Wang (2006) and Denis and Sibilkov (2010).

Finally, we examine the impact of leverage on the market value of receivables. Supporting H5, our results strongly suggest the value of receivables decreases with leverage. This finding is consistent both with Molina and Preve (2009) and with the liquidity source of value for receivables. As leverage increases, bondholders capture a larger portion of the eventual cash flow from the increase in receivables. Our conclusions are unchanged after splitting the sample on industry competitiveness. Statistical inferences are also invariant to splitting the sample according to financial constraint. However, as we would expect, the economic strength of the relationship for $\Delta T R^{\star} L$ is strongest for the constrained subsample because excess leverage is more problematic for financially constrained firms.

\section{Conclusion}

We estimate the market value of trade credit supplied. Our results strongly suggest a significant and positive relation between excess stock returns and changes in receivables. Additional evidence indicates a higher value of receivables for suppliers with stronger motives relating to operating and contracting costs. From this, we infer that the equity market perceives frictions encouraging extensions of trade credit. Equity holders discount the value of receivables held by financially unconstrained firms, relative to constrained firms, consistent with the future liquidity cushion provided by receivables. Overall, our results suggest the importance of supplier financing in enhancing equity value and that the market value impact of receivables depends upon the perceived benefits conferred by this form of financing. Gauging the market's recognition of trade credit extended distinguishes 
our study from prior research focused on the cross-sectional variation in trade credit levels. How the market perceives these motives is crucial as capital markets provide long-term sources of funds that can pay down commercial paper and bank credit lines initially used to finance receivables.

In addition to extending the finance literature, this study has managerial implications regarding trade credit policy. Although suppliers should seek to minimize financing costs associated with carrying receivables on the balance sheet, firms should be cautious when minimizing receivables. Assessing the efficiency of trade credit practices based on traditional ratio analysis may lead to spurious conclusions as other factors should be considered. For example, suppliers may tie up a greater proportion of their sales or assets in receivables, relative to their industry peers, because of their financial strength and/or friction faced by their customers, not lax or inefficient collection efforts.

\section{References}

Almeida, H., M. Campello, and M. Weisbach, 2004, “The Cash Flow Sensitivity of Cash," Journal of Finance 59, 1777-1804.

Atanasova, C., 2007, “Access to Institutional Finance and the Use of Trade Credit," Financial Management 36, 49-67.

Ben-Horim, M. and H. Levy, 1983, "Management of Accounts Receivable Under Inflation," Financial Management 12, 42-48.

Bias, B. and C. Gollier, 1997, “Trade Credit Rationing and Credit Rationing," Review of Financial Studies 10, 903-937.

Bougheas, S., S. Mateut, and P. Mizen, 2009, "Corporate Trade Credit and Inventories: New Evidence of a Trade-Off from Accounts Payable and Receivable," Journal of Banking and Finance 33, 300-307.

Brennan, M., V. Maksimovic, and J. Zechner, 1988, “Vendor Financing," Journal of Finance 43, 1127-1176.

Brick, I. and W. Fung, 1984, "Taxes and the Theory of Trade Debt," Journal of Finance 39, 1169-1176.

Burkart, M. and T. Ellingsen, 2004, "In-Kind Finance: A Theory of Trade Credit," American Economic Review 94, 569-590.

Calomiris, C., C. Himmelberg, and P. Wachtel, 1995, "Commercial Paper, Corporate Finance, and the Business Cycle: A Microeconomic Perspective," Proceedings of the Carnegie-Rochester Conference Series on Public Policy 42, 203-250.

Chevalier, J. and D. Scharfstein, 1996, "Capital Market Imperfections and Countercyclical Markups: Theory and Evidence," American Economic Review 86, 703-725.

Cunat, V., 2006, "Trade Credit: Suppliers as Debt Collectors and Insurance Providers," Review of Financial Studies 20, 491-527.

Deloof, M., 2003, “Does Working Capital Management Affect Profitability of Belgian Firms?” Journal of Business Finance and Accounting 30, 573-587.

Deloof, M. and M. Jegers, 1996, “Trade Credit, Product Quality, and Intragroup Trade: Some European Evidence," Financial Management 25, 33-43.

Denis, D. and V. Sibilkov, 2010, "Financial Constraints, Investment, and the Value of Cash Holdings," Review of Financial Studies 23, 247-269.

Dittmar, A. and J. Mahrt-Smith, 2007, "Corporate Governance and the Value of Cash Holdings," 
Journal of Financial Economics 83, 599-634.

Emery, G., 1984, “A Pure Financial Explanation for Trade Credit," Journal of Financial Quantitative Analysis 19, 271-285.

Emery, G., 1987, “An Optimal Financial Response to Variable Demand," Journal of Financial Quantitative Analysis 22, 209-225.

Emery, G. and N. Nayar, 1998, "Product Quality and Payment Policy," Review of Quantitative Finance and Accounting 10, 269-284.

Fabbri, D. and A. Menichini, 2010, "Trade Credit, Collateral Liquidation, and Borrowing Constraints," Journal of Financial Economics 96, 413-432.

Fama, E. and K. French, 1993, "Common Risk Factors in the Returns on Stocks and Bonds," Journal of Financial Economics 33, 3-56.

Fama, E. and K. French, 1997, "Industry Costs of Equity," Journal of Financial Economics 43, 153-193.

Fama, E. and K. French, 1998, “Taxes, Financing Decisions, and Firm Value," Journal of Political Economy 81, 607-636.

Fama, E. and J. MacBeth, 1973, "Risk, Return, and Equilibrium: Empirical Tests," Journal of Finance $53,819-843$.

Faulkender, M. and R. Wang, 2006, “Corporate Financial Policy and the Value of Cash," Journal of Finance 61, 1957-1990.

Fazzari, S., G. Hubbard, and B. Petersen, 1988, "Financing Constraints and Corporate Investment," Brookings Paper on Economic Activity 19, 141-195.

Ferris, S., 1981, “A Transactions Theory of Trade Credit Use,” Quarterly Journal of Economics 96, 243-270.

Garcia-Teruel, P. and P. Martinez-Solano, 2010, "A Dynamic Approach to Accounts Receivable: A Study of Spanish SMEs," European Financial Management 16, 400-421.

Giannetti, M., M. Burkart, and T. Ellingsen, 2008, “What You Sell is What You Lend? Explaining Trade Credit Contracts," Review of Financial Studies 24, 1-38.

Hausman, J., 1978, “Specification Tests in Econometrics," Econometrica 46, 1251-1257.

Hawawini, G., C. Viallet, and A. Vora, 1986, “Industry Influence on Corporate Working Capital Decisions," Sloan Management Review 27, 15-24.

Hill, M., G. W. Kelly, and M. Highfield, 2010, “Net Operating Working Capital Behavior: A First Look," Financial Management 39, 783-805.

Katz, A. and J. Blatt, 2008, in F. Fabozzi, Ed. The Handbook of Finance, Hoboken, NJ, John Wiley and Sons, Chapter 76, 779-788.

Kim, Y. and J. Atkins, 1978, “Evaluating Investments in Accounts Receivable: A Wealth Maximizing Framework," Journal of Finance 33, 403-412.

Klasa, S., W. Maxwell, and H. Ortiz-Molina, 2009, “The Strategic Use of Corporate Cash Holdings in Collective Bargaining with Labor Unions," Journal of Financial Economics 92, 421-442.

Klemperer, P., 1987, “Markets with Consumer Switching Costs," Quarterly Journal of Economics 102, 375-394.

Lee, Y. and J. Stowe, 1993, "Product Risk, Asymmetric Information, and Trade Credit," Journal of Financial Quantitative Analysis 28, 285-300.

Long, M., I. Malitz, and A. Ravid, 1993, “Trade Credit, Quality Guarantees, and Product Marketability," Financial Management 22, 117-127. 
Longhofer, S. and J. Santos, 2003, “The Paradox of Priority," Financial Management 32, 69-81.

Love, I., L. Preve, and V. Sarria-Allende, 2007, “Trade Credit and Bank Credit: Evidence from Recent Financial Crises," Journal of Financial Economics 83, 453-469.

Maness, T. and J. Zietlow, 2003, Short-Term Financial Management, 3rd Ed., Cincinnati, OH, Thomson- Southwestern.

Meltzer, A., 1960, "Mercantile Credit, Monetary Policy, and Size of Firms," Review of Economics and Statistics 42, 429-437.

Mian, S. and C. Smith, 1992, "Accounts Receivable Management Policy: Theory and Evidence," Journal of Finance 48, 169-200.

Molina, C. and L. Preve, 2009, "Trade Receivables Policy of Distressed Firms and Its Effect on the Costs of Financial Distress," Financial Management 38, 663-686.

Nadiri, M., 1969, “The Determinants of Trade Credit in the US Total Manufacturing Sector," Econometrica 37, 408-423.

Newey, W. and K. West, 1987, “A Simple, Positive Semi-Definite, Heteroskedasticity and Autocorrelation Consistent Matrix," Econometrica 55, 703-708.

$\mathrm{Ng}$, C., J. Kiholm-Smith, and R. L. Smith, 1999, "Evidence on the Determinants of Credit Terms Used in Inter-firm Trade," Journal of Finance 54, 1109-1129.

Opler, T., L. Pinkowitz, R. Stulz, and R. Williamson, 1999, “The Determinants and Implications of Corporate Cash Holdings," Journal of Financial Economics 52, 3-46.

Petersen, M., 2009, “Estimating Standard Errors in Finance Panel Data Sets: Comparing Approaches," Review of Financial Studies 22, 435-480.

Petersen, M. and R. Rajan, 1994, "The Benefits of Lending Relationships: Evidence from Small Business Data," Journal of Finance 49, 3-37.

Petersen, M. and R. Rajan, 1997, "Trade Credit Theories and Evidence," Review of Financial Studies 10, 661-691.

Pinkowitz, L., R. Stulz, and R. Williamson, 2006, “Does the Contribution of Corporate Cash Holdings and Dividends to Firm Value Depend on Governance? A Cross-Country Analysis," Journal of Finance 61, 2725-2752.

Preve, L. and V. Sarria-Allende, 2010, Working Capital Management, 1st Ed., New York, NY, Oxford University Press.

Rauch, J. E., 1999, “Networks Versus Markets in International Trade,” Journal of International Economics 48, 7-35.

Sartoris, W. and N. Hill, 1981, "Evaluating Credit Policy Alternatives: A Present Value Framework," Journal of Financial Research 4, 81-89.

Sartoris, W. and N. Hill, 1983, "A Generalized Cash Flow Approach to Short-Term Financial Decisions," Journal of Finance 38, 349-360.

Scherr, F., 1996, “Optimal Trade Credit Limits," Financial Management 25, 71-85.

Schwartz, R., 1974, "An Economic Model of Trade Credit," Journal of Financial Quantitative Analysis 9, 643-657.

Shin, H. and L. Soenen, 1998, "Efficiency of Working Capital Management and Corporate Profitability," Financial Practice and Education 8, 37-45.

Smith, J., 1987, “Trade Credit and Informational Asymmetry," Journal of Finance 42, 863-871. 